\title{
How plate tectonics is recorded in chalk deposits along the eastern English Channel in Normandy (France) and Sussex (UK)
}

\author{
Anne Duperret ${ }^{1 *}$, Sara Vandycke ${ }^{2}$, Rory N. Mortimore ${ }^{3}$, Albert Genter $^{4}$
}

1. FRE 3102 CNRS Laboratoire Ondes et Milieux Complexes, Université du Havre, 53 rue de Prony, BP540, 76058 Le Havre cedex, France

2. Université de Mons, Faculté Polytechnique, Géologie Fondamentale et Appliquée, 20 place du Parc, 7000 Mons, Belgique

3. University of Brighton and ChalkRock Ltd, 32 Prince Edwards road, Lewes, Sussex BN7 1BE, United Kingdom

4. BRGM, 3 avenue Claude Guillemin, BP36009, 45060 Orléans cedex and GEIE Exploitation Minière de la Chaleur, route de Soultz, BP40038, 67250 Kutzenhausen, France

\section{Abstract}

Intra-plate stresses that occurred in the Anglo-Paris Basin and English Channel during Upper Cretaceous and Cenozoic times are a consequence of the convergence between Eurasia and Africa and the opening of the North Atlantic area. This geodynamic re-organisation is recorded on each side of the English Channel, with the emergence of regional structures such as the the Weald-Artois anticline and the reactivation of large-scale strike-slip faults. We analyse the Anglo-Paris Basin Chalk fracture system, on each side of the eastern English Channel, using a set of 1600 meso-scale fractures data collected on coastal chalk cliffs in Normandy (NW France) and Sussex (UK). Mesoscale fracture system is precisely dated using chalk lithostratigraphy correlations within the basin. Moreover, an inversion method is used on fault slip data to evidence a paleostress chronology in the Anglo-Paris Basin. Three main Upper Cretaceousextensive events, characterized by normal faults and jointing are recorded in Normandy and two Cenozoic compressive and extensive events with strikeslip and normal faults appear in Sussex. Paleostress records vary on each part of the eastern English Channel. The meso-scale fracture system is thus used to better define the type of relationship between meso-scale and large-scale brittle deformation in the Chalk during Meso-Cenozoic. A first NE-SW extension is recorded in Normandy in relation with local anticlines structures and related to the Lower Rhine graben opening. A second event is a WNW-ESE extension of local origin in relation with

corresponding author :

E-mail: anne.duperret@univ-lehavre.fr, Fax : +33 (0)235217198 
the subsidence axis of the Paris Basin. The third event is a NNE-SSW extension, well marked in Normandy and related to the activation of E-W normal faults in the western approaches of the English Channel. This event is also recorded in Sussex and reactivates locally older fractures in strike-slip. The Oligocene N-S compression / E-W extension related to the Pyrenean tectonics and the last E-W extension relative to the North Sea graben opening are well recorded in Sussex, but not in Normandy. Recent far-field stresses developed in the NW European platform are focused on deep crustal structures like the Artois hills and the Cotentin areas in France. These structures act as a stress barrier by protecting the Normandy Chalk from recent far-field stresses. On the contrary, recent farfield stresses are easily recorded by meso-scale brittle deformation on the folded Chalk in Sussex.

\section{Keywords}

Chalk, meso scale fracturing, paleostress, lithostratigraphy, the eastern English Channel, Anglo-Paris Basin, Normandy, Sussex

\section{Introduction}

Upper Cretaceous Chalk of the NW Europe provides an excellent record of brittle tectonics generated by far-field stresses of plate tectonics re-organisation during Meso-Cenozoic. As one of the intra-continental basins of NW Europe, the structural style of the Anglo-Paris Basin is strongly linked to the initial configuration of the basin, but also to the orientation of the basin axis relative to the direction of the greatest horizontal stress and the amount of strain and the lithological composition of its sedimentary infill (Ziegler, 1990). The aim of this study is to explore the precise relationships between meso-scale fracture data, large-scale tectonic lineaments and syn-sedimentary events in the Chalk of the Anglo-Paris Basin. The particularity of chalk deposits is to present a very high variety of lithofacies and syn-sedimentary events (e.g. hardground levels, dolomitisation...), that conducts to subsequent mechanical properties of the chalk at various scales (e.g. Lord et al., 2002 ; Mortimore et al., 2004a).

Previous studies have identified tectonic phases related to the so-called Subhercynian events (Ziegler, 1981, 1990 ; Mortimore et al., 1998) previously defined in the Subhercynian Cretaceous basins in the Harz foreland Germany (Stille, 1924) ; while other studies suggested a paleostress history for structures such as faults, deduced from microstructural analysis (e.g. Bergerat, 1987; Vandycke and Bergerat, 2001 ; Hibsch et al., 1995). 
The eastern English Channel is an ENE-WSW trending basin crossing the north part of the Anglo-Paris Basin, extending along a NW-SE axis from the south of England to the east of France (Figs. 1, 2). During the Mesozoic time, the Anglo-Paris Basin development is related to the continental extension due to the North Atlantic history and to the basin inversion during Cenozoic compression (Ziegler, 1981).

Paleostresses have conducted to inversion along some large-scale North-West European ante-Mesozoic structures, as well as meso-scale brittle fracturing in the chalk cover. To give a more exact timing of the of the deformation in the Chalk located each part of the English Channel and the relationships between brittle deformation type at large-scale and at meso-scale, we choose to study in details two various regions of the Chalk basin. On the one hand, the Normandy coast located near the depot centre of the Chalk basin and characterized by a few large-scale tectonic structures. On the other hand, the East Sussex coast located in the border of the Chalk basin and affected by numerous large scale tectonic lineaments and folding.

We used a data set concentrated on the orientation and frequency of meso-scale fractures from the Chalk in the coastal cliffs of the eastern English Channel (Genter et al., 2004). A new paleostress analysis of Upper-Normandy meso-scale faults has been performed and combined with paleostress studies already undertaken in East Sussex (Vandycke, 2002) in order to establish both the tectonic phase timing and their chronology along the Eastern English Channel during Meso-Cenozoic. Complementary studies have been carried out on chalk sedimentology and fracture type embedded within particular Chalk Formations through out the entire basin. Chalk Formations were dated using the lithostratigraphy concept (Mortimore, 2010) and used to better constrain the age of the meso-scale fracturation.

The first objective of this paper is to present the results of about 1600 meso-scale fracture measurements recorded on the chalk cliffs of the eastern English Channel in Upper Normandy (France) and in East Sussex (UK). The aim of this paper is to better define the changes in stresses over time in the English Channel and associated areas.

Microstructural features (slickenslides) revealed on meso-scale fractures are used (1) to better define the tectonic behaviour of large-scale strike-slip and normal faults in the Chalk in relation with syn-sedimentary events recorded at regional scale, (2) to better constrain Meso-Cenozoic paleostress evolution in the Anglo-Paris Basin around the eastern English Channel. 


\section{Tectonic setting of the eastern English Channel}

\subsection{Ante-Mesozoic basement}

The ante-Mesozoic basement of the English Channel is made of three main blocks, crossing the Channel from north east to south west. These units are (Fig. 1): the Brabant-Midland block, the Rheno-hercynian zone and the Cadomian block (Stoneley, 1982; Autran et al., 1994 ; Guillocheau et al., 2000). Each block is limited by two main tectonic lineaments, i.e. the North Variscan Front (VF) and the Bray Fault, which are considered to have had a great influence on the sedimentation and fracturing of the overlying Mesozoic chalk cover (e.g. Heritier et Villemin, 1971; Shephard-Thorn et al., 1972 ; Chadwick, 1986 ; Autran et al., 1994 ; Mortimore and Pomerol, 1997 ; Guillocheau et al., 2000). Both in Northern France and Southern England, tectonic lineaments associated with the Variscan Front are N110-120E oriented (Shepard-Thorn et al., 1972; Chadwick, 1986; Colbeaux et al., 1980; Lamarche et al., 1998). In NW France, the Bray Fault is oriented NW-SE (N130-140E) and is considered a large pre-Mesozoic ductile dextral strike-slip fault, roughly parallel to the Variscan Front (Matte, 1986; Holder and Leveridge, 1986). The Bray Fault appears to connect to the Sandown anticline (Isle of Wight) in South England, where it presents an E-W orientation.

\subsection{Meso-Cenozoic tectonics in the Chalk}

\subsubsection{Anglo-Paris basin geodynamic context}

The Upper Cretaceous and Cenozoic evolution of North-West Europe was influenced by the progressive opening of the North Atlantic and the onset of the Alpine collision in the Tethys domain (Ziegler, 1981). Rifting phases which preceded the onset of seafloor spreading in the Arctic-North Atlantic are coeval with the early phases of Alpine orogeny (Ziegler, 1975). Far-field intraplate stresses are held responsible for early inversion movements in the Paris Basin and Channel area, related to the convergence between Eurasia and Africa in the western Tethys (Ziegler, 1990; Mortimore and Pomerol, 1997; Robaszynski et al., 2005). The resultant compressional stresses were partly transmitted through the crust of metastable North-West European platform during Upper Cretaceous (Subhercynian phases), during early Paleocene (Laramide inversion phase) and during Late EoceneEarly Oligocene (Ziegler, 1981, 1990).

\subsubsection{The supposed Subhercynian phases}


The Anglo-Paris Basin shows elongated basins and swells, mainly WNW-ESE oriented in UK and NW-SE oriented in France, following the major basement strike-slip faults (Holder and Leveridge, 1986; Matte, 1986 ; Mortimore and Pomerol, 1991; Mortimore, 2010) (Fig.2). The so-called Subhercynian tectonics is expressed in the Upper Cretaceous chalk cover as local uplifts along lineaments related to strike-slip movements on deep variscan structures, created a tectonic topography and hardgrounds in the Chalk (Mortimore et al., 1998). Mortimore et al., 1998 reinvestigated the Upper Cretaceous Subhercynian tectonic events, originally introduced by Stille (1924), in the Subhercynian Cretaceous basins in the Harz foreland Germany. They applied the concepts for the first time to the chalks outside the Subhercynian region, particularly to the Anglo-Paris Basin (Mortimore et al., 1998) and to the onshore - offshore U.K. (Mortimore \& Pomerol, 1997). In these papers Stille's 1924 Ilsede (broadly late Turonian- Early Coniacian), Wernigerode (Late Santonian - Early Campanian) and a third Peine tectonic phase of Riedel $(1940,1942)$ in the Late Lower Campanian were identified in chalk facies.

\subsubsection{Cenozoic inversions}

As noted by Ziegler (1990), basin inversion is considered to be the reversal of the subsidence of a sedimentary basin that had developed in an intra-cratonic setting under a tensional to transtensional stress regime in response to its compressional deformation. Large evidence of inversion has been highlighted in the Channel area, particularly along the coast of the UK and in the Weald-Artois. The large folding of the Upper Cretaceous Chalk outcrops in the Isle of Wight (UK), that involved the compressional reactivation of previously tensional faults, as observed on offshore seismic profiles. The inversion is dated from the end of Eocene to early Miocene, according to different authors (Chadwick, 1993 ; Butler, 1998 ; Gale et al., 1999 ; Vandycke and Bergerat, 2001). The inversion phase is also marked in the East Sussex Chalk exposures, with post Cretaceous meso-scale strike-slip fractures (Vandycke, 2002). Another proof is the progressive up-warping of the Weald-Artois axis since Eocene which had interrupted the marine connection between the southern North Sea and the area of the Western Approaches-Channel Basins at the beginning of the Oligocene (Ziegler, 1990; Ziegler and Dezès, 2007). The Cenozoic evolution of the Paris Basin and the Armorican massif was strongly influenced by wrenches deformations. It is the case with the Bray anticline formation, which appears to localize the deformation in the Paris Basin, with a normal component from Permian to 
Albian, as shown on seismic profiles (Heritier and Villemin, 1971) and inverse component by tectonic inversion since Upper Cretaceous (Wyns, 1980; Tremolières, 1981). Microstructural data have evidenced an additional dextral strike-slip motion after Upper Pliocene, in association with the Bray anticline deformation (Wyns, 1977).

\subsection{Studied areas}

Coastal areas studied in the eastern English Channel are located in Upper Cretaceous chalk deposits along $40 \mathrm{~km}$ on the East Sussex coast (UK) and along $120 \mathrm{~km}$ on the Haute-Normandie Upper-Normandy and Picardy coasts in France. As observed on the ante-Mesozoic basement of the eastern Channel (Fig.1), the coast of East Sussex in UK is entirely located on the Rheno-Hercynian basement whereas the coast of Upper-Normandy in France belongs to the Rheno-Hercynian zone north of the Bray Fault and to the Cadomian block south of the Bray Fault.

The East Sussex coastline is oriented WNW-ESE in folded chalk units and is located between the Weald-Boulonnais anticline and the Eocene Hampshire-Dieppe Basin. The Upper-Normandy coast is also made of Upper Cretaceous chalk bounding the southern submarine part of Hampshire-Dieppe Basin (Fig. 2).

\section{Materials and methods}

\subsection{Lithology and stratigraphy method}

The Upper Cretaceous chalk cliffs of the eastern English Channel comprise Cenomanian to lower Campanian chalk deposits (Mégnien and Mégnien, 1980; Mortimore and Pomerol, 1987). In France, the division of the chalk has traditionally followed the internationally recognised six biostratigraphical stages of the Upper Cretaceous series. The traditional chalk stratigraphy (simply divided into lower, middle and upper chalk) has been completely revised in the UK (Mortimore, 1983, 1986 ; Bristow et al, 1997) and the new terminology for southern England is now used by the British Geological Survey for mapping chalk terrains (BGS, 2006). The chalk lithostratigraphy concept is derived on the basis of recognising broad units of chalk, some nodular or not, some with marl seams or a few. The keys to the lithostratigraphy, however, are the individual marl seam, hardground or flint bands many of which have been correlated over vast distances through northern (Yorkshire) and southern (Devon, Sussex, Kent) provinces of the chalk in UK and the western (Normandy) and 
eastern (Champagne) regions of the Paris Basin in France (e.g. Mortimore and Pomerol, 1997; Mortimore et al., 2001). Main evidence supporting any correlation was provided by macrofossils of the chalk, such as sea urchins or inoceramid bivalves. The detailed bio-and lithostratigraphy were the keys to define a new chalk terminology in East Sussex (Mortimore et al., 2004) and in Normandy (Duperret et al., 2004) and obtain a better chronology on Cenomanian-Campanian chalks (Fig. 3).

In Normandy, Cenomanian Chalk is made of basal glauconitic marl overlying by the Craie de Rouen (Juignet, 1974), a conspicuously rhythmic, coarse hard chalk with banks of harder beds (nodular chalks and hardgrounds) and thick flint bands. In East Sussex, Cenomanian Chalk was traditionally called Lower Chalk and comprises the Grey Chalk subgroup overlying by the Plenus Marls Member. The Grey Chalk subgroup is divided into a lower West Melbury Marly Chalk Formation and an Upper Zig Zag Chalk Formation. The Turonian Chalk comprises the gritty Holywell Nodular Chalk Formation and the smooth New Pit Chalk Formation, which contains numerous marls seams (Mortimore and Pomerol, 1996; Bristow et al., 1997). According to Mortimore et al. (2001), the overlying Lewes Nodular Chalk Formation, with persistent nodular chalk beds is dated from Upper Turonian to Lower Coniacian. The overlying homogeneous pure white Seaford Chalk Formation, with numerous flint bands is dated from Middle Coniacian to Middle Santonian. The Newhaven Chalk Formation is characterized by regular marl seams with sparse flint bands and is dated from Upper Santonian to Lower Campanian. The Culver Chalk Formation of Lower Campanian in age outcrops in East Sussex but is lacking in Normandy cliffs.

These correlations allow an accurate assessment of the age of various chalk exposures and then a detailed chronology of meso-scale fracturing events. On the French Chalk cliffs, about $45 \%$ of the analysed coastline length exposes one lithostratigraphic unit on a vertical cliff section and $50 \%$ of the analysed coastline contains two Chalk formations in the cliff face (Duperret et al., 2004). The fracture occurrence is precisely correlated with the age of chalk exposures on the vertical chalk cliffs.

\subsection{Meso scale fracturing}

A systematic collection of structural data on coastal chalk cliffs outcrops was made for fractures or faults embedded in the chalk units, during the Interreg II funded ROCC project (Genter et al., 2004). Measures of fractures planes (azimuth, dip, striations if measurable) were made on 1362 meso-scale fractures reported on 26 study sites in Normandy and on 274 fractures reported on 7 
study sites in East Sussex. Ten to hundreds of individual structures were observed and measured on each site. The average fracture density along cliffs is low with a mean value of 0.074 fracture/m along the Normandy coast (Genter et al., 2004).The occurrence of shear movements such as slickensides, striation, vertical offsets of flint layers was used to determine the presence of faults. Most of the observed meso-faults have undergone only one phase of slip and consequently display only one generation of striation. On the cliffs, the main fracture types collected in the field were normal faults, strike-slip faults, master-joints and joints with steep dipping (Fig. 4). (1) Normal faults (Fig. 4a,b) are steeply dipping fractures and present a sliding-mode (mode II), evidenced on the cliff face with typical apparent offsets of $\mathrm{cm}$ to metric scale. In some cases vertical slickensides were observed as well as a cataclased damaged zone associated to the major fault plane. (2) Strike-slip faults (mode III, with tearing) were determined through the occurrence of sub-horizontal slickensides on fault planes. They have been commonly reported in East Sussex and rarely in Normandy (Fig. 5c). (3) Master-joints (mode I) are open nearly vertical fractures that cross the whole cliff with an apparent length of tens to hundred of meters. They are tiny and partly open fractures whose vertical trace may be underlined by Fe-oxide coloration. As they show no indicator of movement on the cliff face and no slickenside on the fracture plane, they are defined as master-joints (mode I, with opening) (Fig. 5e). (4) Joints (mode I) represent small-scale fractures (Fig. 5 d,f) with no indication of movement. They are isolated fractures or organized in more pervasive vertical network embedded within the chalk units. (5) Some fractures are characterized by $5-10 \mathrm{~mm}$ thick filling made of flint or calcite. Flint infilled fractures are commonly observed in the field, but slightly isolated at outcrop scale. The black flint infill seal the fracture and no slickenside can be observed on these planes, as well as no relative displacements of lithological markers on the cliff face. Most of the fractures with flint infill show a sinuous and/or curved track on the cliff face and on the shore platform, with a thick flint infill mainly concentrated in the wide portions of the fracture. Nevertheless, in some places such as Newhaven (UK) in the upper part of the Newhaven Chalk Formation, flint infill normal faults are reported. These faults show a differential apparent visible offset of markers on the cliff face, with a higher shift at the base of the cliff than at the top. Such faults are called normal synsedimentary faults by Vandycke (2002) and growth faults by Mortimore (2010). Due to the complexity of silicification processes in the chalk, flint infill fractures have not been considered with a specific treatment. Some others fractures with calcite infill have been observed in East Sussex particularly within the oldest chalk unit dated from Cenomanian (West Merlbury Marly 
Chalk Formation). Most of these fractures are planar and may show slickensides. They have thus been considered as faults where slickensides are measured.

As also observed in the chalk layers at Flamborough head, in east England, some fracture sets are poorly linked and discontinuous whereas some others are fully linked and have developed into a normal fault (Larsen and Gudmundsson, 2010). Most of the normal faults reported in this study are fully linked fractures, with slickensides. Discontinuous set of fractures are considered as joints, due to the lack of striation on fault plane.

The vertical length of fractures (from 1 to about $100 \mathrm{~m}$ ) is closely linked to the cliff height exposure, but their horizontal extension has not been reported systematically. Only a little portion of large-scale fractures may only be recognized on the shore platform during low tide, as observed on aerial photographs.

\subsection{Inversion method for paleostress analysis}

The inversion method used for fault slip data analysis has been described in details in Angelier (1990) and successfully applied in the western European platform by Bergerat (1987) and Vandycke (2002). The method consists of determining the best-fitting reduced paleostress tensor for a given fault slip data set, thus identifying the attitude of the three principal stress axis (maximum, intermediate and minimum stress: $\sigma_{1}, \sigma_{2}$ and $\sigma_{3}$ respectively) and the ratio $\Phi=\left(\sigma_{2}-\sigma_{3}\right) /\left(\sigma_{1}-\sigma_{3}\right)$ of principal stress magnitudes. As chalk deposits are made of sub-horizontal bedding, the paleostress succession has been easily established without data rotation to integrate ante or post-folding tectonics. The main guide used for distinguishing the different fault sets is the consideration of the age of rocks affected by a deformation type using the chalk lithostratigraphy scale and the characterisation of the fracture type.

\section{Coastal chalk cliff analysis in eastern English Channel}

\subsection{Large-scale regional geology and fault pattern}

In Upper-Normandy, coastline orientation is roughly perpendicular to folded and large-scale brittle structures (Fig. 5). Cretaceous chalk units of Normandy are slightly undulating along a NNWSSE axis. From SW to NE, two main tectonic lineaments (the Fécamp-Lillebonne Fault and the Bray Fault) appear to delineate three tecto-sedimentary areas in the Chalk basin (Fig. 5). (1) the Caux region with a NNE dip of Cenomanian to Coniacian chalks up to the Fécamp-Lillebonne Fault, (2) the 
central block is made of chalks from Turonian to Campanian forming the main axis valley in the Bembridge-Saint Valery en Caux syncline, centred at Quiberville, where the youngest chalk units are exposed east of Saint Aubin sur Mer town (Newhaven Chalk Formation, Lower Campanian in age), (3) North-East of the Bray Fault, Turonian-Coniacian chalks mainly folded along the Londinière and Bresle anticline axes. The main brittle deformation at large scale is concentrated on the two regional lineaments: the Fécamp-Lillebonne Fault and the Bray Fault (Fig. 5). Variable subsidence rates occur between blocks delineated by these two faults during Cenomanian and Lower to Middle Turonian (Juignet, 1980).

The Fécamp-Lillebonne Fault is a major N150-160E normal fault, with a westward offset of $150 \mathrm{~m}$ (Dollfus, 1929) and some recent reactivation as witnessed by the historic seismicity recorded in 1747 near Fécamp (Lemoine, 1911, Lambert et al., 1996). As noted by Mégnien (1971), the FécampLillebonne Fault represents the northern branch of the Seine fault in Normandy. The N150-160E Fécamp-Lillebonne and Seine faults are relayed by a N60 transverse lineament: the Villequier-Pavilly fault. The Fécamp-Lillebonne Fault displays condensed series of Upper Coniacian chalks to the west (Yport location) with chalk thickness reduction and uplifted chalk series from Cenomanian to Upper Coniacian to the east (visible at cap Fagnet, Fécamp, on a $103 \mathrm{~m}$ high cliff). The present-day FécampLillebonne Fault was active during Upper Cretaceous (Lasseur et al., 2009) and is a well documented tecto-sedimentary boundary for the Upper Turonian and Coniacian chalks (Mortimore, 2010). In addition, the Villequier-Pavilly fault induces a vertical offset of $25 \mathrm{~m}$ on Pliocene deposits (Clozier and Kuntz, 1974) and 4m on Holocene deposits (Lefebvre et al., 1974). These observations reinforce the idea that the Fécamp-Lillebonne Fault is a normal fault with a Cenozoic activity.

The Bray Fault is a major crustal fault (Matte, 1986), with a normal component from Albian to Lower Cretaceous and inverted during Upper Cretaceous in relation with the Bray anticline deformation evidenced inland (Wyns, 1980). Upper-Cretaceous normal faulting of the Bray Fault is proposed due to the chalk thickness variations of Turonian to Coniacian chalks from each part of the Bray Fault (Mortimore and Pomerol, 1987; Lasseur et al., 2009). On the coast, a vertical stratigraphic shift of lithological markers is reported on each part of the Bray Fault, with the Seven sister's flint band the Bedwell's columnar flint of Upper Coniacian (in the Seaford Chalk Formation) at Dieppe (west part of the Bray Fault) and the Lewes Marl and Navigation hardground of Upper Turonian (Lewes Nodular 
Chalk Formation) at Puys (eastern part of the Bray Fault) (Mortimore, 2010). This evidences postSantonian activity along the Bray Fault, with an uplift of the northeastern block.

\section{2. meso scale fracturing and paleostresses in Upper Normandy}

26 sites have been studied in details in Upper-Normandy and Picardy. Cliffs are made of Upper Cretaceous Chalk and surficial Cenozoic deposits on $120 \mathrm{~km}$ long coastline, with a vertical profile morphology varying from a few meters high (valleys) to $103 \mathrm{~m}$ in height at Fécamp. These sites are regularly spaced between Le Tilleul valley and Ault town and they cover chalk units from Upper Cenomanian grey chalk to the Campanian Newhaven chalk Formation. Their detailed lithostratigraphy is given in Figure 6 .

\subsubsection{Fracture analysis}

The most common striking orientation recognized on meso-scale brittle structures is oriented NW-SE (N120-130E) (Fig. 5). Most of the master-joints and normal faults present high dips, except in some specific locations, such as at Mers-les-Bains where some normal faults present dips of $20^{\circ}$. The statistical analysis of brittle fracture types (Table1) indicates a large proportion of joints (37\%) and a similar percentage of master-joints (29\%) and normal faults (29\%) along the $120 \mathrm{~km}$ long coastal cliffs (Table 1). The large amount of joints and master-joints versus normal faults is indicative of a high sensibility of the chalk rocks to brittle tectonics under the influence of palaeo-stresses (e.g. Lord et al., 2002; Mortimore et al., 2004; Duperret et al., 2005).

The detailed analysis of meso-scale fracturing is conducted from SW to the NE of the coast. Southwest of the Fécamp-Lillebonne Fault, a set of NNE-SSW (N20) meso-scale normal faults and two strike-slips faults oriented NW-SE (N120) and NNE-SSW (N20) are reported at Le Tilleul (TuroConiacian chalks). At Yport (Coniacian chalks), only NW-SE joints and master-joints are measured on the cliff face. On the other side of the Fécamp-Lillebonne Fault (to the northeast), at cap Fagnet (Fécamp), most of the meso-scale fractures are NW-SE (N120) joints and master-joints. It can be noted a lack of meso-scale faults near the Fécamp-Lillebonne Fault. The same observation is made near the Bray Fault, where only three E-W normal faults are reported at Dieppe. 
Northeast of the Fécamp-Lillebonne Fault to Saint Valery en Caux, a large part of the mesoscale fracturing is represented by joints and master-joints, with a main NW-SE orientation, and local transverse jointed sets observed in Saint Pierre en Port (NNE-SSW) and in Petites Dalles (NE-SW). In Santonian to Campanian chalks of the Bembridge-Saint Valery en Caux syncline, NE-SW masterjoints and normal faults are well expressed, with additional NNW-SSE normal faults in Veules les Roses and Quiberville.

Northeast of the Bray Fault, NE-SW normal faults and master joints are reported on all visited sites. A secondary NNE-SSW set of normal faults is reported at Puys, Criel sur Mer and Bois de Cise, whereas another set of E-W normal faults is reported to the northeast at Mers and Penly. Strike-slip faults are reported in this sector, but on few brittle structures. They are located near the Bray Fault at Puys (on N60E and N100E faults) and Criel sur Mer (N130E) and they attest a strike-slip component near the Bray Fault.

\subsubsection{Paleostresses in Upper-Normandy}

States of stresses are derived from a selected set of mesofractures, where striations were observed and measured in the field. Data used are presented on table 2. Four stratigraphic levels were investigated: Turonian (36 normal faults), Turonian-Coniacian (19 normal faults and 1 strike-slip fault), Santonian (17 normal faults) and Campanian (1 normal fault and 1 strike-slip fault). Three extension phases appear: (a) NE-SW extension, (b) WNW-ESE extension and (c) NNE-SSW extension (Fig. 7). (1) The NE-SW extension shows scattered trends of faults and only recorded by Turonian chalk units, through conjugate stratabound normal faults located at Senneville sur Fécamp in the New Pit Chalk Formation (Middle Turonian) and at Eletot in the basal Lewes Nodular Chalk Formation (Lower Turonian) and at Saint Martin plage in the Holywell Nodular Chalk Formation (Lower Turonian). This extension is confined on specific chalk units with very few flint occurrence and numerous marls, dated from Lower to Upper Turonian. It is expressed on marly chalk units located north of the Fécamp-Lillebonne Fault in association with the Fécamp anticline and north of the Bray Fault in association with the Londinières axis. This event is post-Turonian in age.

Some of the meso-scale normal faults revealed in the field show NW-SE trends, similar to the Fécamp-Lillebonne Fault geometry (Fig. 5). This is an argument to assume that the FécampLillebonne Fault was reactivated after Turonian. 
The post-Turonian NE-SW extension is active during the Coniacian and had a role on the resulting thickness of the chalk deposits on each part of the Fécamp-Lillebonne and Bray Faults, as observed by Juignet (1980), Mortimore and Pomerol (1987), Lasseur et al. (2009). The reactivation of regional faults may be linked to the post-Turonian NE-SW extension recorded at regional scale.

(2) The WNW-ESE extension is recorded by Turonian-Coniacian chalk units, mainly on two areas. On the western part of the studied area, this event has been recognized on stratabound conjugated normal faults at Senneville sur Fécamp and Eletot (Middle to early Upper Turonian). The WNW-ESE extension could be related to the NE-SW extension also observed on the same strata, by an effect of tensor axis inversion (Angelier and Bergerat, 1983), between $\sigma 2$ and $\sigma 3$.

On the eastern part of the studied area, this tectonic event is also observed at Puys through east dipping isolated normal faults with flint infill, measured on the Lewes Nodular Chalk (Middle Turonian) and the overlying Seaford Chalk (Middle Coniacian). The global trend (N-S) of these faults is the same than the Varenne valley axis, which is connected to the Bray Fault axis (Fig 5).

A post Lower Coniacian extension event may thus be identified near the Bray Fault in association with the Varenne fault formation. In addition, this period corresponds to a major lithological change in the chalk sedimentation, when the coarse, nodular Lewes Chalk change to smooth, purer, white Seaford Chalk (Mortimore and Pomerol, 1997).

(3) The NNE-SSW extension is the youngest one as revealed on Turonian to Santonian chalks exposures and is well recorded on all observed sites in Upper Normandy. Most of the meso scale normal faults, master-joints and joints revealed in the field show similar trends (Fig. 5). We can thus assume that this post-Santonian extensive event is largely recorded in Normandy and must be related to a regional tectonic activity in the NW European platform.

The post-Santonian event is calculated from scattered trends data on Santonian chalk units located in Veules-les-Roses and Saint-Aubin in the Bembridge-St Valery en Caux syncline axis. The slight scattering of data may be explained by the occurrence of the Newhaven Chalk Formation, that appears to mechanically favour the occurrence of conjugate faults systems, as observed in East Sussex, UK (Mortimore et al., 2004b; Mortimore, 2010).

A NNE-SSW extension phase is also well expressed in north of France, on Albo-Aptian to Santonian deposits in the Boulonnais (N France), where normal faults are assumed to be older than 
the latter NW-SE and NE-SW extensional systems recorded in Boulonnais (Vandycke and Bergerat, 1992).

(4) One strike-slip fault and one normal fault are recorded at Quiberville in the Campanian Newhaven Chalk Formation (table 1). Unfortunately, two faults data are not enough to calculate any tensor. Nevertheless, slickensides may be indicative of a post-Campanian WSW-ENE strike-slip event in transtension, only expressed in the Campanian Chalk in Normandy, in relation with a fault reactivation, located at Quiberville. This strike-slip fault may be indicative of the slight tectonic inversion expressed in Normandy, probably in relation with the Bray Fault inversion. Similar explanation has been proposed in the Mons Basin where a major strike-slip event, Campanian in age, is related to the activity of the North Artois Shear Zone (Vandycke et al., 1991). In add, Mortimore (2010) reports a normal fault occurrence in the Saane valley, located between Quiberville and Sainte Marguerite sur Mer, where the Quiberville hardground is restrained southwest of the Saane valley in the basal Campanian.

\section{Coastal chalk cliff analysis in East Sussex, UK}

\subsection{Large-scale geology and fault pattern}

Tectonics of Sussex and the Isle of Wight is mainly related to WNW-ESE extensional faulting from Permian to early Cretaceous (Chadwick, 1986 ; Lake and Karner, 1987) and following inversion along an E-W oriented structural axis (Underhill and Stoneley, 1998 ; Vandycke, 2002), leading to the development of hanging wall anticlines during Eocene and Oligocene (Hawkes et al., 1998) and to exhumation of deep rocks during Palaeocene (Hillis et al., 2008).

In contrast to the French coast, geological structures of East Sussex coastline plunge southwestward, along a WNW-ESE axis parallel to the coastline (Mortimore and Pomerol, 1991) (Fig. 8). On the coastline, large-scale fractures are not as developed as folding. A set of E-W folds controls the distribution of Chalk formations and coastal morphologies (Mortimore et al., 2004b). Natural headlands are located on small anticline axes, such as Beachy Head, Seaford Head and Friar's Bay anticlines (Mortimore and Pomerol, 1991; Mortimore, 2010). Some of the syncline axes are occupied by river valleys, favouring chalk erosion, such as along Cuckmere river, eastward of Hope Gap, and along Ouse river, eastward of Newhaven. Cuckmere valley is guided by a complex strike-slip fault lineament with a normal component (Jevington-Cuckmere fault) giving a stratigraphic offset from each part of the 
valley, as observed on onshore seismic profile acquired in 1976 (Mortimore and Pomerol, 1991), whereas the Ouse river is suspected to be guided by a N150E strike-slip fault (Newhaven fault), giving the straight morphology of the Newhaven valley. The Jevington-Cuckmere fault and the Newhaven fault separate respectively the Eastbourne, Seaford and Brighton Chalk blocks (Mortimore et al., 2004b) (Fig. 8).

\subsection{Lithostratigraphy of each site}

The study area in East Sussex was focused on $40 \mathrm{~km}$ long coastline. 7 sites were studied in details and the lithostratigraphy chart is summarized on Figure 9. On East Sussex coastline, Beachy Head coastal cliffs reach $150 \mathrm{~m}$ high in front of the lighthouse, whereas to the west, the cliffs are lower (20-40m high). This is the reason why the Beachy Head section presents chalk exposures from Cenomanian to Coniacian stage (Fig. 8). Cenomanian chalks exposes continuously from Eastbourne (Holywell beach) (NE) to Cow Gap and the Beachy Head lighthouse (SW). This coastal section provides a progressive exposure from east to west of various Cenomanian chalk units at the base of the cliff, due to the westward plunge of the Beachy Head anticline. The oldest chalk unit is the West Melbury Marly Chalk (Lower and Middle Cenomanien) that is exposed at the cliff base from Cow Gap to Falling sands. This unit is progressively replaced by Zig Zag Chalk formation (Middle and Upper Cenomanian) and Holywell Chalk formation (Upper Cenomanian) to the Beachy head lighthouse. The Birling Gap valley is the axis of a syncline plunging westward, where only pure white Seaford Chalk Formation (Middle Coniacian to Middle Santonian) is exposed. West of the Cuckmere fault, Coniacian chalk appears at Hope Gap and is progressively replaced at the base of the cliff by Santonian and Campanian chalks to the west. From Seaford Head to Saltdean (and Brighton), the cliff is entirely made of Campanian, with Newhaven Chalk Formation overlain in some places by the youngest Culver Chalk Formation exposed at Seaford Head point, due to the E-W anticline deformation of the chalk (Seaford Head anticline).

\subsection{Meso-scale fracturing}

\subsubsection{Fracture analysis}

Fracture measurements were taken on 7 sites in East Sussex. The most common striking orientations are N20-60E (NNE-SSW), N150-170E (NNW-SSE) and N120-130E (NW-SE). The percent on fracture types (Table 2) indicate a large proportion of strike-slip faults at Cow Gap (in 
Cenomanian chalk units) and at Peacehaven and Telscombe (in Campanian chalk unit). Normal faults have been recorded at each site, except at Birling Gap, where only joints and master-joints are embedded within the Coniacian chalk. The occurrence of both conjugate strike-slip faults and normal faulting provides the evidence for compressive and extensive paleostress events along the Sussex coastline (Vandycke, 2002). In Cenomanian chalk units of Beachy Head, normal faults may show large vertical displacements of several meters and a large proportion of strike-slip and normal faults recorded in the non-flinty Zig Zag Chalk Formation are filled with thick geodic calcite mineralisation. For example, some of these faults show striations on the calcite infill, which is indicative of two phases of faulting with a late post-infilled displacement.

On Cenomanian units at Cow Gap (Fig. 8), NNE-SSW conjugate normal faults are predominant. They are associated with isolated normal faults NW-SE oriented and conjugate NNWSSE and NNE-SSW strike-slip faults.

Coniacian chalk units exposed at Hope gap contain isolated master-joints oriented NNE-SSW, NNW-SSE and NW-SE, like the whole coastal meso-fracturing, with a few NE-SW normal faults. Coniacian-Santonian chalk (Seaford Chalk Formation) exposed at Birling Gap is affected by WNWESE and NNE-SSW jointing (joints) with some large isolated master-joints. Mortimore (2001) noted the exceptional purity of the Seaford Chalk Formation at this location, where chalk contains very few marl seams, which favours vertical fracture style (Mortimore, 1979).

Coniacian-Santonian-Campanian chalk units exposed at Seaford Head evidence again NNESSW normal and strike-slip faults, with an isolated NW-SE normal fault set parallel to the coastline. Campanian chalk units exposed at Newhaven, Peacehaven and Telscombe highlight conjugate NNESSW normal faults and NNE-SSW and NNW-SSE strike-slip faulting. At Newhaven, the occurrence of two sets of conjugate master-joints oriented NNE-SSW and NNW-SSE gives to the Newhaven Chalk Formation a typical pyramidal fracturing framework (Mortimore, 1979, 2010; Mortimore et al., 2004b). In contrast to chalk formations without marl seams (such as Seaford Chalk Formation in Sussex, as observed at Birling Gap) where fracture sets are predominantly characterized by vertical jointing, conjugate and slickenside normal and strike-slip faults appears mainly as restrained to chalk formations with numerous marl seams, such as the Newhaven Chalk Formation (Mortimore, 2001, 2010). 


\subsubsection{Paleostress timing}

Paleostresses have been determined on Sussex coast from a large set of 205 meso-scale faults (strike-slip and normal faults) recorded from Eastbourne to Saltdean on Cenomanian to Campanian chalks, where four main tectonic phases were defined (Vandycke, 2002). The paleostress history recorded in chalk in Sussex is characterized by an extensional regime interrupted by a major Eocene-Oligocene inversion (N-S compression/ E-W extension) with strike-slip fault system development and following by an E-W extensive phase (Butler, 1998 ; Butler and Pullan, 1990 ; Chadwick, 1993 ; Vandycke, 2002).

The various tectonic phases are reconsidered to define a better chronology between events, using the detailed chalk lithostratigraphy of Grey Chalk (Cenomanian) and White Chalk (Turonian to Campanian) well exposed along the British coastline (Fig. 10).

(1) The NNE-SSW extension/ ESE-WNW compression is determined from the conjugate strike-slip faults measured at Cow Gap and Falling sands on Cenomanian chalks along the Beachy Head anticline and at Seaford Head on Coniacian chalks along the Seaford Head anticline (Fig. 10, 11). On Cenomanian chalks, the NNE-SSW extension/ ESE-WNW compression is calculated from faults with striations on calcite infill. The compressive stress axis $(\sigma 1)$ is in the obtuse angle but this can be due the reactivation of previous structure and/or the low number of data. It can be interpreted as a late displacement on a previous NNE-SSW set of synsedimentary faults, as also noted by Vandycke (2002). A similar NNE-SSW extension marked by strike-slip meso-faults is also recorded on various chalk outcrops on the Isle of Wight, where it occurred before the main folding. Paleostress tensors are determined from strike-slip faults showing synsedimentary character (faults are sealed by a continuous level of chalk and flints in the Culver Chalk Formation) (Vandycke and Bergerat, 2001). This is an argument to assume a Campanian or post-Campanian synsedimentary activity for this tectono-sedimentary event. As emphasized by Mortimore and Pomerol (1991, 1997), syn-Upper Cretaceous tectonic movements are recognized along tectonic axes, where each phase rejuvenates the tectonic topography which is subsequently buried by chalk deposit with post-tectonic chalk facies changes. Mortimore and Pomerol (1997) suggest that the conjugate style of faulting/jointing in the Newhaven Chalk Formation may be linked to a Subhercynian phase, also recognized in the Isle of Wight, in the Whitecliffe section over the Sandown anticline. It is characterized by the anomalous 
sedimentation of the "flintless belt" with numerous hardgrounds (Late Santonian to Early Campanian) and synsedimentary local slumps in the vicinity of the Sandown anticline (Mortimore and Pomerol, 1991; Mortimore et al., 1998).

(2) The N-S compression/E-W extension, characterised by conjugate strike-slip faults appears in Turonian at Beachy Head and at Telscombe in the Campanian (Newhaven Chalk Formation). This tectonic phase does not appear on Coniacian units located at Birling Gap and Hope Gap (Fig. 10, 11) and is not recorded on the oldest chalk units of Middle Cenomanian. The N-S compression/E-W extension is also well represented on another set of 81 fracture data recorded on Campanian chalks at Newhaven, Peacehaven, Greenwich meridian, Telscombe and Saltdean and at Glynde (Vandycke, 2002).

(3) The younger tectonic event is an E-W extension that appears on Cenomanian, Turonian, Coniacian and Campanian chalk units, but is not evidenced on Coniacian-Santonian chalks at Birling Gap, where fracturing is mainly represented by joints and master-joints. The E-W extension phase is very well expressed in the Isle of Wight, where it is suggested to result from strain release after the $\mathrm{N}$ S compression/E-W extension (Vandycke and Bergerat, 2001). The E-W extension also corresponds to the opening direction of the northern part of North Sea basins (Ziegler, 1989). In add, E-W extension system has been reported in the Kent (UK) and Boulonnais (France) and dated of postSantonian in relation with the opening of the North Sea (Bergerat and Vandycke, 1994). Our analysis of data precise a post-Campanian age for the E-W extension event.

\section{Discussion}

Upper Cretaceous and Cenozoic times were periods of plate reorganisation in NW Europe, with transition from extensional to compressional tectonics, inducing various states of stresses through the European platform. However, plate tectonics states of stresses are recorded in various ways on each region of the chalk basin in NW Europe, depending on of the location in the chalk basin and of the of pre-Mesozoic large-scale tectonic lineaments periodically reactivated and also depending on of the chalk units "sensibility" to far-field stresses. 
(1) The NE-SW extension recorded in the chalk of Upper Normandy is the oldest event identified in this study. This event is not recognized in the chalk of East Sussex, nevertheless it is widely recognized in Boulonnais (northeast of Normandy in France) in Albian to Santonian formations, in the chalk of Kent (southwest of Sussex in UK) (Bergerat and Vandycke, 1994), and in the Maastrichtian chalk of the Mons Basin (Belgium) (Vandycke et al., 1991), where the NE-SW extension is dated from Upper Maastrichtian.

In Normandy, the NE-SW extension is only recorded in the Turonian chalks at specific locations, where are exposed marly chalk units (the New Pit Chalk Formation, Hollywell Chalk Formation and basal Lewes nodular Chalk Formation) in relation with folds associated to the Fécamp anticline and the Londinières axis (Penly anticline). We propose that these Chalk Formations are more sensitive to regional stresses than older and younger Chalk formations, due to their high marl contents. This NE-SW extension may be linked to the opening of the Lower Rhine graben located southeast in the European platform, in the southern part of the North Sea system. The Rhine graben extension begins at the end of Cretaceous and allows strike-slip motion along the North Artois Shear Zone in Boulonnais (Colbeaux, 1974) and right lateral motion in the Mons Basin during lower Maastrichtian (Vandycke et al, 1988, 1991 ; Vandycke and Bergerat, 1989, Vandycke, 2002). This long distance state of stress is not reported southwest of the Fécamp-Lillebonne Fault in the Turonian chalk units exposed at Le Tilleul. The Fécamp-Lillebonne appears to act as a buttress fault that stops the propagation of tectonic stresses to the southwest.

According to paleogeographic and paleotectonic reconstruction of NW Europe (Ziegler, 1988), the NE-SW extension (phase I) recorded in Normandy may provides from the opening of the southern part of the North Sea and the Lower Rhine graben, during Paleocene.

(2) The WNW-ESE extension is reported in Turo-Coniacian chalks in Normandy, but not in East Sussex. This extensive system appears to be only of regional origin, with some faults developed in the same marly chalk units than the NE-SW extension phase (New Pit Chalk Formation). Two hypotheses may be suggested to explain the origin of this extensive system. On one hand, the WNW-ESE extension system could be related to the NE-SW extension also observed on the same strata, by an effect of tensor axis inversion, between $\sigma 2$ and $\sigma 3$. On the other hand, the WNW-ESE extension 
system may be related to differential subsidence in the chalk of the Paris Basin. During Middle to Upper Turonian, the Paris Basin recorded a migration of subsidence from the Normandy area to the centre of the basin (to the southeast), evidenced on isopach maps by an increase of the chalk thickness to the centre of the Paris Basin (Lasseur, 2007). The subsidence of the basin that increases to the southeast may generate a local WNW-ESE extension in Normandy with chalk formations more sensitive to brittle deformation. It is the case of the New Pit Chalk Formation.

In Normandy, the WNW-ESE extension postdates NE-SW extension. Tectonic data suggest a post-Maastrichtian phase, nevertheless comparisons with paleogeographic data established during Paleocene (Ziegler, 1988) indicates that WNW-ESE extension (phase II), only recorded in Normandy, could be dated from Paleocene.

(3) The NNE-SSW extension is the last event reported in Turonian to Santonian chalks in Normandy and the first one in Sussex reported in Cenomanian chalks in association with the Beachy Head anticline and in Turo-Coniacian chalks in association with the Seaford Head anticline. The NNE-SSW extension is focused on previous folded structures, such as the Beachy Head and the Seaford Head anticlines. The NNE-SSW extension is also recognized in Boulonnais (Bergerat and Vandycke, 1994) and inland in Sussex (Vandycke, 2002) but with scattered trends. The NNE-SSW extension/ESEWNW compression recognized in the Isle of Wight is determined from synsedimentary strike-slip faults active at the Campanian, before the Cenozoic inversion. This brittle tectonics is associated to disturbances in the chalk sedimentation in relation with the Sandown anticline. In Normandy, ESEWNW joints and normal faults system are well developed and recognized on all study sites. east of the Fécamp-Lillebonne Fault, one ESE-WNW lineament is also evidenced as a major structural lineament with Cenozoic reactivation, based on fractal analysis of talwegs network in the chalk (Hauchard et al., 2002). The NNE-SSW extension system may originate from western plate dynamics, such as the opening of the Hampshire-Dieppe Basin in association with the activation of the E-W normal faults of the Western Approaches Basin and the eastern Channel Basin. The opening of the western approaches may be recorded very early in the Campanian chalk of the Isle of Wight, just before the Cenozoic inversion and latter in Sussex and in Normandy.

During Late Oligocene, the Western approaches in western part of the English Channel and the eastern English Channel were opening. In the same time, the Weald-Artois anticline was merged, 
conducting to link SW England and NW France (recent Pas-de-Calais strait) (Ziegler, 1988). The NNE-SSW extension (phase III) recorded in Normandy may be related to the English Channel opening, whereas the WNW-ESE compression / NNE-SSW extension (phase III) recorded in Sussex during the same period, may be favoured by the uplift of the Weald Artois (WNW-ESE trend), that had guided the propagation of NNE-SSW stresses from the Upper Rhine graben opening to SW England (in Sussex).

(4) The N-S compression/E-W extension system is recorded with strike-slip conjugated faults on Turonian to Campanian chalks in Sussex. The N-S compression/E-W extension with strike-slip is also recorded in the Isle of Wight in the Upper Cretaceous chalk as well as in the clays of the Bembridge beds dated from Oligocene (Vandycke and Bergerat, 2001). .

Transpressional strike-slip events are also recognized locally in some other places in NW European chalk: in Lower Cenomanian Chalk in Boulonnais (North France), in the Kent (UK), in the Maastrichtian Chalk of Mons Basin (Belgium), in NE Belgium and in the Isle of Wight (Vandycke, 2002). In Boulonnais, strike-slip event may be linked to the right-lateral motion of the North Artois Shear Zone during Lower Cenomanian (Vandycke and Bergerat, 1992). In the Mons Basin, strike-slip event created a Riedel system of faults with pull-apart geometry in chalk formations (Vandycke et al., 1991). It is dated from Early Maastrichtian and relative to the Laramide inversion (Vandycke, 1992). In the Isle of Wight, the N-S compression/E-W extension brittle tectonics phase is linked to inversion tectonics and developed before, during and after the flexure process, from Late Eocene to Oligocene (Vandycke and Bergerat, 2001). This could correspond to the so-called Pyrenean compressive event, as also recorded during Eocene-Oligocene times in Southern North Sea, Hampshire Basin, Channel basins and Western Approaches (Ziegler, 1990). The N-S compression is also well known over a large part of the west European platform and related to the Pyrenean tectonic phase (Letouzey, 1986; Bergerat, 1987). In the chalk of NW Europe, strike-slip events appear thus as brittle tectonics linked to the inversion phase at various periods.

Even If two strike-slip faults are recorded in Normandy, only in the youngest chalk units (SantonianCampanian) located in the Bembridge Saint-Valery syncline axis, there is no evidence of a strike-slip motion recorded near or in association with the Fécamp-Lillebonne Fault and the Bray Fault. The Oligocene N-S compression may be related to the Pyrenean tectonics, recorded along an east-west 
axis of folded chalk units, located north of the eastern English Channel (Isle of Wight, East Sussex, Kent, Boulonnais, Belgium). The lack of N-S compression system in Normandy, particularly along large-scale lineaments, may be correlated with the low folding (only slight undulations of the chalk deposits) observed in this part of the chalk basin. The N-S compression appears to concentrate along the North Artois Shear Zone to the North East (Boulonnais and Belgium) and along reverse and strikeslips faults observed in the Cotentin (Lagarde et al., 2000, 2003) to the South West.

During Late Oligocene, N-S compression of Pyrenean tectonics (Ziegler, 1988) is recorded in Sussex with strike-slip faults, that have developed during N-S compression / E-W extension (phase IV).

(5) The E-W extension (phase V) is the youngest event recorded on all chalk units in Sussex. It is also recorded in the Isle of Wight, in Kent, in Boulonnais and in Belgium. As noted by Ziegler (1989) and Vandycke and Bergerat (1994), the E-W extension system is related to the opening of northern basins of the North Sea and the Rhine graben. By correlation with the previous event recorded in Sussex, we suggest that the E-W extension is post-Oligocene in age. The lack of the E-W extension in chalks of Normandy may be explained by the occurrence of the trending WNW-ESE Artois hills, located between the chalk basin of Picardy to the south west and the Flanders plain to the north east. Artois hills are remainder of the Weald-Artois anticline, eroded to the west in Boulonnais and Kent. The Artois alignments correspond to small, fault-related anticlines resulting from the early Tertiary tectonic inversion dated from Miocene to Pliocene (Colbeaux et al., 1993) or Late Oligocene to middle Miocene (Ziegler, 1988; Ziegler and Dezès, 2007). The Artois hills appear to limit the E-W extensive stress propagation from the North Sea grabens to the south west. This reinforce the idea that Weald-Artois anticline is a major crustal structure that limits stress propagation in the chalk cover up to the basement (Mansy et al., 2003).

\section{Conclusion}

State of stresses induced by plate tectonics in NW Europe is recorded on different ways in the Chalk located on each side of the English Channel in Normandy and Sussex. The analysis of mesoscale faulting using inversion method for fault slip data reveal various paleostresses in Upper Cretaceous Chalk of Normandy and Sussex. Paleostresses records are correlated in age using 
lithostratigraphy concept in the Chalk and the evolution of the brittle deformation is analysed in relation to large-scale lineaments and in relation to the geodynamic context of NW Europe since Upper Cretaceous (Fig. 11).

The Normandy coast is located near the depot centre of the Anglo-Paris Basin and is crossed by two large-scale transverse faults. Inversion analysis of meso-faults shows three successive extensive events, with normal faulting. The first one is a NE-SW extension (phase I) marked in marly chalk units exposed within anticline structures developed near Fécamp and Penly, in relation to the opening of the Rhine graben (South of North Sea) dated of Paleocene. The second event is a WNWESE extension (phase II) of local origin (stress permutation or chalk thickness variations), also dated of Paleocene. The third and last event recorded in Normandy is also recorded in Sussex in previously fractured and folded chalk units. It is the NNE-SSW extension (phase III) that may be related to the opening of the Hampshire-Dieppe Basin in association with the activation of the E-W normal faults of the Western Approaches Basin and the eastern Channel Basin, during Late Oligocene.

The chalk of Normandy has recorded meso-scale brittle tectonics related to the southern part of the North Sea opening (Rhine graben) and the western approaches opening. However, large-scale faults (Fécamp-Lillebonne Fault and Bray Fault) are not reactivated during these events. In fact, largescale faults are associated to regional folds and appear to stop the propagation of the brittle deformation from far-field stresses and act as large transverse buttress.

The Sussex coast is located in the border of the Anglo-Paris Basin with a complex system of en échelon folds. Folds appear to concentrate the brittle deformation with the reactivation of previous meso-scale fractures as strike-slip faults during the NNE-SSW extension/ESE-WNW compression (phase III), relative to the Oligocene Western Approaches opening and the OligoceneN-S compression/E-W extension (phase IV) relative to the Pyrenean tectonics. Finally, the E-W extension system related to the north of North Sea opening system (phase V) during middle Miocene is recorded in Sussex.

In the Normandy Chalk, very few traces of compressive and strike-slip tectonics are found. Only one meso-scale strike-slip fault recorded in a syncline structure may be related to the Pyrenean compressive tectonics. The lack of reactivation of large-scale faults in Normandy during Pyrenean tectonics could be explained by a concentration of stresses along the Artois hills (to the north) and along the Cotentin in the Armorican Massif (to the south). The same reason may be evoked to explain 
the lack of E-W extension in Normandy. These deep crustal structures appear to protect the Normandy Chalk from recent far-field stresses. On the contrary, recent far-field stresses are easily recorded by meso-scale brittle deformation on the folded Chalk in Sussex.

\section{Acknowledgements}

This work was undertaken as part of INTERREG II project ROCC funded by the European Union (contract 199059). We thank students who have participated with us in fracture field acquisition on coastal chalk cliffs, with enthusiasm during PNRN and ROCC project, both in France and UK : Emmanuel Piffard, Baptiste Delacourt, Mick de Pomerai and more specifically Alexandra MartinezFalgon and James Lawrence. We acknowledge Francoise Bergerat and Agust Gudmundsson, editors of this volume, for their constructive reviews that led to significant improvements. S.V. is a research associate of the National Research Foundation of Belgium.

\section{References}

Angelier J., 1990. Inversion of field data in fault tectonics to obtain the regional stress-III. A new rapid direct inversion method by analytical means. Geophysics Journal International, 103, 363-376.

Angelier J. et Bergerat F., 1983, Systèmes de contraintes et extension intracontinentale. Bulletin du centre de Recherche Exploration-Production Elf Aquitaine, 7 (1), 137-147.

Autran A., Lefort J-P., Debeglia N., Edel J.B., Vigneresse J.L, 1994, Gravity and magnetic expression of terranes in France and their correlation beneath overstep sequences, in J.D. Keppie (ed) : Pre-Mesozoic geology in France and related areas, Springer-Verlag Berlin Heidelberg, 49-72.

Badley M.E., Price J.D., Backshall L.C., 1989, Inversion, reactivated faults and related structures: seismic examples from the southern North Sea. In : Cooper M.A. and Williams G.D. (eds) Inversion Tectonics. Geological society, London, Special Publication, 44, 201-219.

Bergerat F., 1987, Stress fields in European platform at the time of Africa-Eurasia collision. Tectonics, 6, 2, 99-132.

Bergerat F. and Vandycke S., 1994, Cretaceous and Tertiary fault systems in the Boulonnais and Kent areas: paleostress analysis and geodynamical implications. Journal of the Geological Society of London, 151, 439-448.

British Geological Survey, 2006,. England and Wales, sheet 319/334 Lewes and Eastbourne, Sheet 318/333 Brighton and Worthing. 1:50 000 scale geology series map. 
Bristow R., Mortimore R.N., Wood C.J., 1997, Lithostratigraphy for mapping the chalk of southern England. Proceeding's of the Geologist's Association, 109, 293-315.

Butler M., 1998, The geological history of the southern Wessex Basin- a review of new information from oil exploration. In: Underhill, J.R.(ed.), Development, Evolution and Petroleum Geology of the Wessex Basin, Geological Society, London, Special Publications, 133, 67-86.

Butler M. and Pullan C.P., 1990, Tertiary structures and hydrocarbon entrapment in the Weald Basin of the Southern England. In: Hardman, R.F.P. \& Brooks, J. (Eds.), Tectonic Events Responsible for Britain's Oil and Gas Reserves. Geological Society Special Publication 55, 371-391.

Chadwick R.A., 1986, Extension tectonics in the Wessex Basin, southern England. Journal of the Geological Society, 143, 465-488.

Chadwick R.A., 1993. Aspects of basin inversion in southern Britain. Journal of the Geological Society $150,311-322$.

Clozier L. and Kuntz G., 1974, Geological map : Yvetot, scale : 1/50 000, ed. BRGM.

Colbeaux J.P., 1974. Mise en évidence dune zone de cisaillement Nord-Artois. Comptes Rendus de l'Académie des Sciences de Paris, 278,1159-1161.

Colbeaux J.P., Dupuis C., Robazynski F., Auffret J.P., Haesaerts P., Sommé J., 1980, Le détroit du Pas-de-Calais : un élément dans la tectonique de blocs de l'Europe nord-occidentale. Bulletin d'information des géologues du Bassin de Paris, 17, 41-54.

Colbeaux J.P., Amedro F., Bergert F., Bracq P., Delay F., Dupuis, C., Lamouroux, C., Robaszynski, F., Somme, J., Vandycke, S., Vidier, J. P., 1993, Un enregistreur des épisodes tectoniques dans le bassin de Paris: Le Boulonnais, Bulletin de la Société Géologique de France, 1993, Vol. 164, Issue 1, pp. 93-102.

Dollfus G.F., 1929, La faille de Bolbec-Lillebonne (Seine-inférieure). Bull. Serv. Geol. Fr, Paris, 4, 29, $235-250$

Duff P.M.Mc L.D. and Smith A.J., 1992, Geology of England and Wales, The Geological Society, London.

Duperret A., Genter A., Martinez A. and Mortimore R.N., 2004, Coastal chalk cliff instability in NW France : the role of lithology, fracture pattern and rainfall, in : Mortimore R.N. and Duperret A. (eds), Coastal chalk Cliff Instability. Geological Society, London, Engineering Geology Special Publications, 20, 33-55. 
Gale A.S., Jeffrey P.A., Huggett J.M., Connoly P., 1999, Eocene inversion of the Sandown Pericline, Isle of Wight, Southern England, Journal of the Geological Society, 156, 327-339.

Genter A., Duperret A., Martinez A. and Mortimore R.N., Vila J-L, 2004, Multiscale fracture analysis along the French chalk coastline for investigating erosion by cliff collapse, in : Mortimore R.N. and Duperret A. (eds), Coastal chalk Cliff Instability. Geological Society, London, Engineering Geology Special Publications, 20, 57-74.

Guillocheau F., Robin C., Allemand P., Bourquin S., Brault N., Dromart G., Friedenberg R., Garcia JP., Gaulier J-M., Gaaumet F., Grosdoy B., Hanot F., Le Strat P., Mettraux M., Nalpas T., Prijac C., Rigollet C., Serrano O., Grandjean G., 2000, Meso-Cenozoic geodynamic evolution of the Paris Basin : 3D stratigraphic constraints, Geodinamica Acta 13, 189-246.

Hauchard E., Laignel B., Delahaye D., 2002, Proposition d'un nouveau schéma structural du NordOuest du bassin de Paris reposant sur l'analyse fractale de la morphologie des réseaux de thalwegs et les données récentes de la géologie régionale. C.R. Géosciences, 334, 295-302.

Hawkes P.W., Fraser A.J., Einchcomb C.C.G., 1998, The tectono-stratigraphic development and exploration history of the Weald and Wessex Basins, Southern England, UK. In : Underhill J.R. (ed) Development, Evolution and Petroleum geology of the Wessex basin. Geological Society Special Publications, 133, 39-65.

Héritier F. and Villemin J., 1971, Mis en évidence de la tectonique profonde du bassin de Paris par l'exploration pétrolière. Bulletin du BRGM, (2), 11-30.

Hibsch C., Jarrige J.J., Cushing E.M., Mercier J., 1995, Palaeostress analysis, a contribution to the understanding of basin tectonics and geodynamic evolution. Example of the Permian/Cenozoic tectonics of Great Britain and geodynamic implications in western Europe, Tectonophysics, 252, 103-136.

Hillis R.R., Holford S.P., Green P.F., Doré A.G., Gatliff R.W., Stoker M.S., Thomson K., Turner J.P., Underhill J.R., Williams G.A., 2008, Cenozoic exhumation of the southern British Isles, Geology, $36,5,371-374$.

Holder M.T. and Leveridge B.E., 1986, Correlation of the Rhenohercynian Variscides. Journal of the Geological Society, London, 143, 141-148. 
Juignet P., 1974, La transgression crétacée sur la bordure orientale du massif armoricain. Aptien, Albien, Cénomanien de Normandie et du Maine. Le stratotype du Cénomanien. Thèse de Doctorat d'état, Université de Caen, France, 806p.

Juignet P., 1980, Transgressions-régressions, variations eustatiques et influences tectoniques de l'Aptien au Maastrichtien dans le bassin de Paris occidental et sur la bordure du Massif armoricain, Cretaceous Research, vol.1, 341-357.

Lagarde J.L., Baize S., D. Amorese, Delcaillau B., Font M., Volant P., 2000, Active tectonics, seismicity and geomorphology with special reference to Normandy (France), Journal of Quaternary Science, Volume 15, Issue 7, 745-758.

Lagarde J.L., D. Amorese, M. Font, E. Laville and O. Dugué, 2003, The structural evolution of the English Channel area, Journal of Quaternary Science, Volume 18, Issue 3-4, 201-213.

Lake S.D. and Karner G.D., 1987, the structure and evolution of the Wessex Basin, Southern England : an example of inversion tectonics, Tectonophysics, 137, p. 347-378.

Lamarche J., Bergerat F. and Mansy J-L., 1998, Déformations cassantes et plicatives dans le Jurassique du Boulonnais (France), influence lithostructurale et héritage paléozoïque. Comptes Rendus de l'Académie des Sciences, Paris, 326, p. 57-63.

Lambert J., Levret-Albaret A., Cushing M., Durouchoux C., 1996, Mille ans de séismes en France: catalogue d'épicentres, paramètres et références, Ouest éditions, presses académiques, Nantes, 75p.

Larsen B. and Gudmundsson A., 2010, Linking of fractures in layered rocks: implications for permeability, Tectonophysics, 492 (2010), 108-120.

Lasseur E., 2007, La craie du Bassin de Paris (Cénomanien-Campanien, Crétacé Supérieur). Sédimentologie de faciès, stratigraphie séquentielle et géométrie 3D, Thèse de Doctorat de I'Université de Rennes 1, France, 423p.

Lasseur E., Guillocheau F., Robin C., Hanot F., Vaslet D., Coueffe R., Neraudeau D., 2009, A relative water-depth model for the Normandy Chalk (Cenomanian-Middle coniacian, Paris Basin, France) based on facies patterns of metre-scale cycles, Sedimentary Geology, 213, 1-2, 1-26.

Lefebvre D., Huault M.F., Guyader J., Giress P., Hommeril P., Larsonneur C., 1974, Le prisme alluvial de la Seine : synthèse sédimentologique, stratigraphique et paléogéographique. Bulletin d'Information des Géologues du Bassin de Paris, 39, 27-36. 
Lemoine P., 1911, Les tremblements de terre du bassin de Paris, leurs relations avec les accidents tectoniques, Bulletin de la Société Géologique de France, 4, 11, 341-412.

Letouzey J., 1986, Cenozoic paleo-stress pattern in the Alpine foreland and the structural interpretation in a platform basin. Tectonophysics, 132, 215-231.

Lord, J.A., Clayton, C.R.I. \& Mortimore, R.N., 2002, The engineering properties of chalk. Construction Industry Research and Information Association (CIRIA), London, Report 000-2001, 279 p.

Mansy J.L., Manby G.M., Averbuch O., Everaerts M., Bergerat F., van Vliet-Lanoe B., Lamarche J. and Vandycke S., 2003. Dynamics and inversion of the Mesozoic Basin of the WealdBoulonnais area : role of basement reactivation, Tectonophysics, 373, 161-179.

Matte P., 1986, La chaîne varisque parmi les chaînes paléozoïques péri-atlantiques, modèle d'évolution et position des grands blocs continentaux au Permo-Carbonifère, Bulletin de la Société Géologique de France, (8), 2, n¹, 9-24.

Mégnien C., 1971, Observations sur les ondulations tectoniques du bassin de Paris et hypothèse sur une dislocation majeure du socle, Bull. BRGM, 1, 2, 31-40.

Mégnien C.L. and Mégnien F., 1980, synthèse géologique du bassin de Paris. Stratigraphie et Paléogéographie, vol.I, Mémoire du Bureau de Recherches Géologiques et Minières n¹01, Orléans, France.

Mortimore R.N., 1979, The relationship of stratigraphy and tectonofacies to the physical properties of the white Chalk of Sussex, unpubl. PhD thesis, CNAA, Brighton University.

Mortimore R.N., 1983, The stratigraphy and sedimentation of the Turonian-Campanian in the southern Province of England, Zitteliana, 10, 27-41.

Mortimore R.N., 1986, Stratigraphy of the Upper Cretaceous White Chalk of Sussex. Proceedings of the Geologists' Association, 97, 97-139.

Mortimore R.N., 2001, Report on mapping of the Chalk Channel coast of France from Port du HavreAntifer to Ault, June-September 2001, unpublished report, Brighton University.

Mortimore R.N., 2010, Review: A chalk revolution: What have we done to the Chalk of England?, Proceedings of the Geologists' Association, doi: 10.1016/j.pegola.2010.09.001.

Mortimore R.N. and Pomerol B., 1987, Correlation of the Upper Cretaceous White chalk (Turonian to Campanian) in the Anglo-Paris Basin, Proceeding of the Geologist's Association, 98, 97-143. 
Mortimore R.N. and Pomerol B., 1991, Upper tectonic disruptions in a placid Chalk sequence in the Anglo-Paris Basin, Journal of the Geological Society, London, 148, 391-404

Mortimore R.N. and Pomerol B., 1996, A revision of Turonian litho- and biostratigraphy in the AngloParis Basin, Mitt. Geol.-Paläont. Inst., Univ. Hamburg, 77, 423-441.

Mortimore R.N. and Pomerol B., 1997, Upper Cretaceous tectonic phases and end Cretaceous inversion in the chalk of the Anglo-Paris Basin, Proceeding of the Geologist's Association, 108, $231-255$

Mortimore R.N., Wood C., Pomerol C., Ernst G., 1998, Dating the phases of the Subhercynian tectonic epoch: Late Cretaceous tectonics and eustatics in the Cretaceous basins of northern Germany compared with the Anglo-Paris Basin. Zbl. Geol. Paläont. Teil I, 1996 (11/12), 1349-1401.

Mortimore R.N., Wood C.J., Gallois R.W., 2001, British Upper Cretaceous Stratigraphy. Geological Conservation Review Series, $n^{\circ} 23$, Joint Nature Conservation Comitee, Peterborough.

Mortimore R.N., Stone K.J., Lawrence J., Duperret A., 2004a, Chalk physical properties and cliff instability. in : Mortimore R.N. and Duperret A. (eds), Coastal Chalk Cliff Instability, Geological Society, London, Engineering Geology Special publications, 20, p. 75-88.

Mortimore R.N., Lawrence J., Pope D., Duperret A., Genter A., 2004b, Coastal cliff geohazards in weak rock: the UK chalk cliffs of Sussex, in : Mortimore R.N. and Duperret A. (eds), Coastal chalk Cliff Instability. Geological Society, London, Engineering Geology Special Publications, 20, 3-31.

Riedel L., 1940, Uber eine tektonische phase and der Wende Quadraten-Mucronaten-Senon (Peiner phase) in Nordwest-Deutschland. Zeitschrift der deutschen geologischen Gesellschaft, 92, 253258.

Riedel L., 1942, Das Mesozoiken in Niedersachsen-Obere Kreide. Schr. Wirtschaftswiss. Ges. Z. Studium Niedersachsens e. V. F. 2: 52pp, Oldenburg.

Robazynski F., Pomerol B., Masure E., Bellier J-P., Deconinck J-F., 2005, Stratigraphy and stage boundaries in reference sections of the Upper Cretaceous Chalk in the east of the Paris Basin; the 'Craie 700' Provins boreholes, Cretaceous Research, Vol. 26, Issue 2, 157-169.

Shephard-Thorn E.R., Lake R.D. and Atitullah E.A., 1972, Basement control of structures in the Mesozoic rocks of the strait of Dover region, and its reflexion in certain features of the present 
land and submarine topography, Philosophical Transactions of the Royal Society London, A, 272, 99-113.

Smith A.J. and Curry D., 1975, The structure and geological evolution of the English Channel, Phil. Trans. R. Soc. London A., 279, 3-20.

Stille H., 1924, Grundfragen der vergleichenden Tektonik. Berlin (Borntraeger).

Stoneley R., 1982, The structural development of the Wessex Basin. Journal of the Geological Society, London, 139, 545-552.

Trémolieres P., 1981, Mécanismes de la déformation en zones de plateforme et application au bassin de Paris. Rev. Inst. Fr. Pétrole, 36, (4-5) 395-593.

Underhill J.R. and Stoneley R., 1998, Introduction to the development, evolution and petroleum geology of the Wessex Basin. In : Underhill J.R. (ed) Development, Evolution and Petroleum geology of the Wessex basin. Geological Society Special Publications, 133, 1-18.

Vandycke S., 1992, Tectonique cassante et paléocontraintes dans les formations crétacées du NordOuest européen. Implications géodynamiques. thèse de doctorat, Université de Paris VI, 92-02, 179pp.

Vandycke S., 2002, Paleostress records in Cretaceous formations in NW Europe: extensional and strike-slip events in relationships with Cretaceous-Tertiary inversion tectonics, Tectonophysics, 119-136.

Vandycke S. et Bergerat F., 1989, Analyse microtectonique des déformations cassantes dans le Bassin de Mons. Reconstitution des paléo-champs de contrainte au Crétacé-Tertiaire. Annales de la Société Géologique de Belgique, 112, 479-487.

Vandycke S., Bergerat F., Dupuis C., 1988, Paléo-contraintes à la limite Crétacé-Tertiaire dans le Bassin de Mons (Belgique). Implications cinématiques. Relations avec la zone de Cisaillement Nord Artois. Comptes-Rendus de l'Académie des Sciences de Paris, 307, 303-309.

Vandycke S., Bergerat F., Dupuis C., 1991, Meso-Cenozoic faulting and inferred paleostresses of the Mons Basin (Belgium). Tectonophysics, 137, 171-219.

Vandycke S. and Bergerat F., 1992, Tectonique de failles et paléo-contraintes dans les formations crétacées du Boulonnais (N France). Bulletin de la Société Géologique de France, 163 (5), $553-$ 560. 
Vandycke S. and Bergerat F., 2001, Brittle tectonic structures and paleostress analysis in the Isle of Wight, Wessex Basin southern UK, Journal of structural Geology, 23, 393-406.

Wyns R., 1977, Tectonique récente dans l'ouest du bassin de Paris : méthodes d'étude et bilan des déformations plio-quaternaires, Bulletin de la Société Géologique de France, 7, 12, 681-684.

Wyns R., 1980, Apports de la microtectonique à l'étude de l'anticlinal du pays de Bray : proposition d'un mécanisme de pli en compression avec décrochements associés, Bulletin de la Société Géologique de France, 7, 19, 1093-1101.

Ziegler P.A., 1975, Geologic evolution of the North sea and its tectonic framework. American Association of Petroleum Geologists Bulletin, 59, 7, 1073-1097.

Ziegler P.A., 1981, Evolution of sedimentary basins in north-west Europe. In : Illing L.V. \& Hobson G.D. (eds) Petroleum Geology of the Continental shelf of North-West Europe, Heyden, London, 3-39.

Ziegler, P.A., 1988, Evolution of the Arctic-North Atlantic and the Western Tethys. American Association of Petroleum Geologists Memoir 43, 164-196.

Ziegler P., 1989. Geodynamic model for Alpine intra-plate compressional deformation in Western and Central Europe . In Cooper M.A. and Williams G.D. (editors). Inversion Tectonics, Geological Society, London, Special Publications, 44, 63-85.

Ziegler P.A., 1990, Geological atlas of Western and Central Europe. Shell International Petroleum Maatschappij B.B.

Ziegler P.A. and Dezès P., 2007, Cenozoic uplift of Variscan Massifs in the Alpine foreland: Timing and controlling mechanisms, Global and Planetary Change, 58, 1-4, 237-269.

\section{Figure Captions}

Figure 1: The ante-Mesozoic basement in South England and North France. The main lineaments and blocks delimitations located in France are adapted from Autran et al. (1994) and Guillocheau et al. (2000). The English Channel and South England (Wessex Basin) are compiled from Stoneley (1982) and Lake and Karner (1987). NASZ: North Armorican Shear Zone ; SASZ: South Armorican Shear 
Zone, NEF: Nort sur Erdre Fault. IoW : Isle of Wight. Figure 2 location is indicated. The studied areas locations are also indicated (Fig. 5 and 8 )

Figure 2: The Eastern English Channel simplified geological map, with the tectonic lineaments and undulations, adapted from Smith and Curry (1975). SW England and NW France are represented using low resolution DEM (Digital Elevation Model). The linkages between offshore and terrestrial tectonic lineaments are adapted from Lake and Karner (1987) Guillocheau et al. (2000), Mortimore (2010). The schematic eastern English Channel's geological cross section, adapted from Ziegler (1990), Duff and Smith (1992), Mortimore (2010). The lines are main undifferentiated lineaments: lines with squares are normal faults and lines with triangles are inverse faults. The lines with double arrows are anticlinal axes. The black boxes are locations of the study areas in Upper Normandy, France and in East Sussex, UK.

Figure 3: Chalk lithostratigraphic units and chronology, with formations used in Sussex (Southern province, UK) and Normandy (France), adapted from Mortimore, 1986, 2001; Bristow et al., 1997 ; Mortimore et al., 2001, 2004b. The correlations with local chalk units already defined in France are added (Lasseur, 2007).

Figure 4: Examples of brittle fracturing in the Cretaceous chalk of the Normandy and Sussex coastal cliffs. The large scale normal faults along all cliff height are evidenced by flint levels offsets (a) in the Lewes Chalk Fm and overlying Seaford Chalk Fm at Puys (France) and by striations on the fault planes (b) in the Newhaven chalk Fm at Quiberville (France). The strike-slip faults are evidenced by horizontal striations (c) on the faults planes in the Newhaven chalk Fm at Peacehaven (UK). Joints and master-joints do not show any striations on fault planes, as observed on intra-bedded joints (d) in the Newhaven chalk Fm at Sainte Marguerite sur Mer (France) and on the Seaford Chalk Fm at Birling Gap (UK), on joints with no striations (f) and master-joints (g) crossing all the cliff height.

Figure 5: DEM mapped with simplified geology of Upper Normandy (France) and geological section of the chalk cliffs from Antifer Cape to Ault, covering a distance of $120 \mathrm{~km}$ long and showing cliff face exposures varying from 20 to $103 \mathrm{~m}$ high, with a vertical exaggeration of 100 . Cenozoic and 
Quaternary deposits are not represented. The grey scales are similar on the map and the section and correspond to the various stages of Upper Cretaceous. The geological data are adapted from the 1/250 000 Rouen geological map (BRGM), except for the Bembridge-St Valery en Caux syncline compiled from Smith and Curry (1975). The cartographic projection of the map is in Lambert II. Abbreviations of the geological section are : TIL : Le Tilleul, ETR: Etretat, YP: Yport, FC: Fécamp, SF : Senneville sur Fécamp, EL : Eletot, SPP : Saint Pierre en Port, PD: Petites Dalles, GD : Grandes Dalles, VLT: Veulettes sur Mer, SVC: Saint Valéry en Caux, VLR: Veules Les Roses, SA: Saint Aubin sur Mer, QB: Quiberville, SM: Sainte Marguerite sur Mer, PO: Pourville, DP : Dieppe, PY: Puys, SMP: Saint Martin plage, PEN : Penly, CRI : Criel sur Mer, MER : Mers les Bains, BDC : Bois de Cise, AUL : Ault.

Fracture data azimuths measured on 26 sites are reported as rose diagram for each type of fracture. 392 normal faults are reported on 21 sites. 8 strike-slip faults are reported on 3 sites at Criel sur Mer (1), Puys (5), Le Tilleul (2). 392 masterjoints are reported on 20 sites, 506 joints are reported on 19 sites. See Table 1 for more details.

Figure 6: The synthetic chalk stratigraphy and chalk units Formations of the cliff face is reported for each studied coastal site in upper Normandy. The various stages are deduced from the Chalk lithostratigraphy analysis, using key-markers. The grey scale reproduces the chronological stages, as detailed at left on the diagram. The horizontal bold lines indicate the recognition of a typical keymarker in the field. For some site (Le Tilleul and Criel sur Mer), a report is made on the NE and the SW sides of the site.

Figure 7: Paleostress analysis in Normandy, only deduced from faults with measured striations. The stereographic projections are on lower Schmidt diagrams, with striaes orientations indications (arrows). The stars are principal paleostress axes $\left(\sigma_{1}, \sigma_{2}, \sigma_{3}, 5,4,3\right.$ stars respectively, $\left.\sigma_{1}>\sigma_{2}>\sigma_{3}\right)$. The main extension directions are black arrows. The numbers indicate site location, where paleostress tensor for extensional phases are calculated. The oldest event is a NE-SW extension recognized on Turonian chalks at (2) Senneville sur Fécamp, (3) Eletot, (8) Saint Martin-plage. A WNW-ESE extension is recognized on Turonian at (1) Le Tilleul, (2) Senneville sur Fécamp, (3) Eletot and on Turonian-Coniacian at (7) Puys. A youngest NNE-SSW extension is recognized on Turonian at (1) Le 
Tilleul, (2) Senneville sur Fécamp, (8) Saint Martin-plage, (10) Mers les Bains, on Turonian-Coniacian at (7) Puys, (9) Criel sur Mer, (11) Bois de Cise, (12) Ault, on Santonian Chalks at (4) Veules-lesRoses, (5) Saint Aubin, (6) Quiberville. Roman letters are indicative of the events chronology. A : southern tectonic block, B : central tectonic block, C : northern tectonic block. See Table 3 for more details

Figure 8: DEM mapped with simplified geology of East Sussex (UK). Cenozoic and Quaternary deposits are not represented. The white lines represent major rivers. Geological data are adapted from the $1 / 50000$ scale geology series maps of BGS, sheet 318/333 Brighton and Worthing and sheet 319/334 Lewes and Eastbourne, published in 2006.

304 Fracture data azimuths measured on 6 sites located between Brighton and Eastbourne are reported as rose diagram for each type of fracture. 59 normal faults are reported on 7 sites. 49 strikeslip faults are reported on 6 sites. 47 masterjoints are reported on 4 sites, 149 joints are reported on 4 sites. See Table 2 for more details.

Figure 9: The synthetic Chalk stratigraphy of the cliff face is reported for each studied coastal sites in East Sussex. The various stages are deduced from chalk lithostratigraphic analysis, using keymarkers. The grey scale reproduces the chronological stages, as detailed at the left of the diagram. The horizontal bold lines indicate the recognition of a typical key-marker in the field. For some sites (Telscombe, Newhaven, Seaford Head and Beachy Head) numerous sections are shown as a function of stratigraphic variations observed along the explored area.

Figure 10: the paleostress analysis on Cenomanian to Campanian sites in East Sussex (UK), deduced from normal and strike-slip fauts. The geological section of the chalk cliffs from Brighton to Eastbourne is reported with a vertical exaggeration of 50 to evidence folds. The numbers indicate study sites on the coastal chalk cliffs where paleostresses are calculated: (1) Saltdean, (2) Telscombe, (3) Greenwich meridian, (4) Peacehaven, (5) Newhaven, (6) Hopegap, (7) Birling Gap, (8) Beachy Head, (9) Eastbourne. See Table 3 for more details. Roman letters are indicative of the events chronology. 
Figure 11: Synthetic view of paleostress field evolution recorded in the Upper Cretaceous Chalk of Normandy (France) and Sussex (UK). Events I to V are reported, from the older to the youngest. The chronological expansion of each event is given using the stratigraphy of the fractured chalk units. In Normandy (I) is the NE-SW extension, (II) is the NW-SE extension, (III) is the NNE-SSW extension. In East Sussex, (III) is the same than in Normandy with a NNE-SSW extension/ESE-WNW compression, (IV) is the N-S compression/E-W extension, (V) is the E-W extension.

Table 1:

Fracture type numbering per study sites in Normandy. Tectonic blocks limits are the same than on Fig. 7.

Table 2:

Fracture type numbering per study sites in East Sussex (UK).

Table 3:

Stress tensor determination from measured faults with slikenslides. Columns from left to right are as follows. (1) Sites, number corresponding to localities indicated on Figure 7 for Normandy, on Figure 10 for Sussex, (2) Stratigraphy of the chalk affected by faulting, (3) number of fault slip data used for computation $(\mathrm{N}),(4)$ trends and plunge of principal stresses axes $\sigma 1, \sigma 2, \sigma 3$ calculated by direct method inversion (INVDIR, Angelier, 1990), (5) ratio $\Phi=(\sigma 2-\sigma 3 / \sigma 1-\sigma 3), \alpha$ is the average angle between computed shear stress and observed slickenslide lineation, (6) ratio "upsilon" (RUP, ranging between $0 \%$ and $200 \%$ ) of the INVDIR method; (7) average RUP between values below $50 \%$ indicate good fits between actual fault slip data and computed shear distributions, (8) Tectonic regimes : mainly extension in Normandy, extensional $(E)$ or strike-slip $(X)$ in Sussex. The approximate direction indicated before " $X$ " is $\sigma 1$, before " $E$ " is $\sigma 3$. 


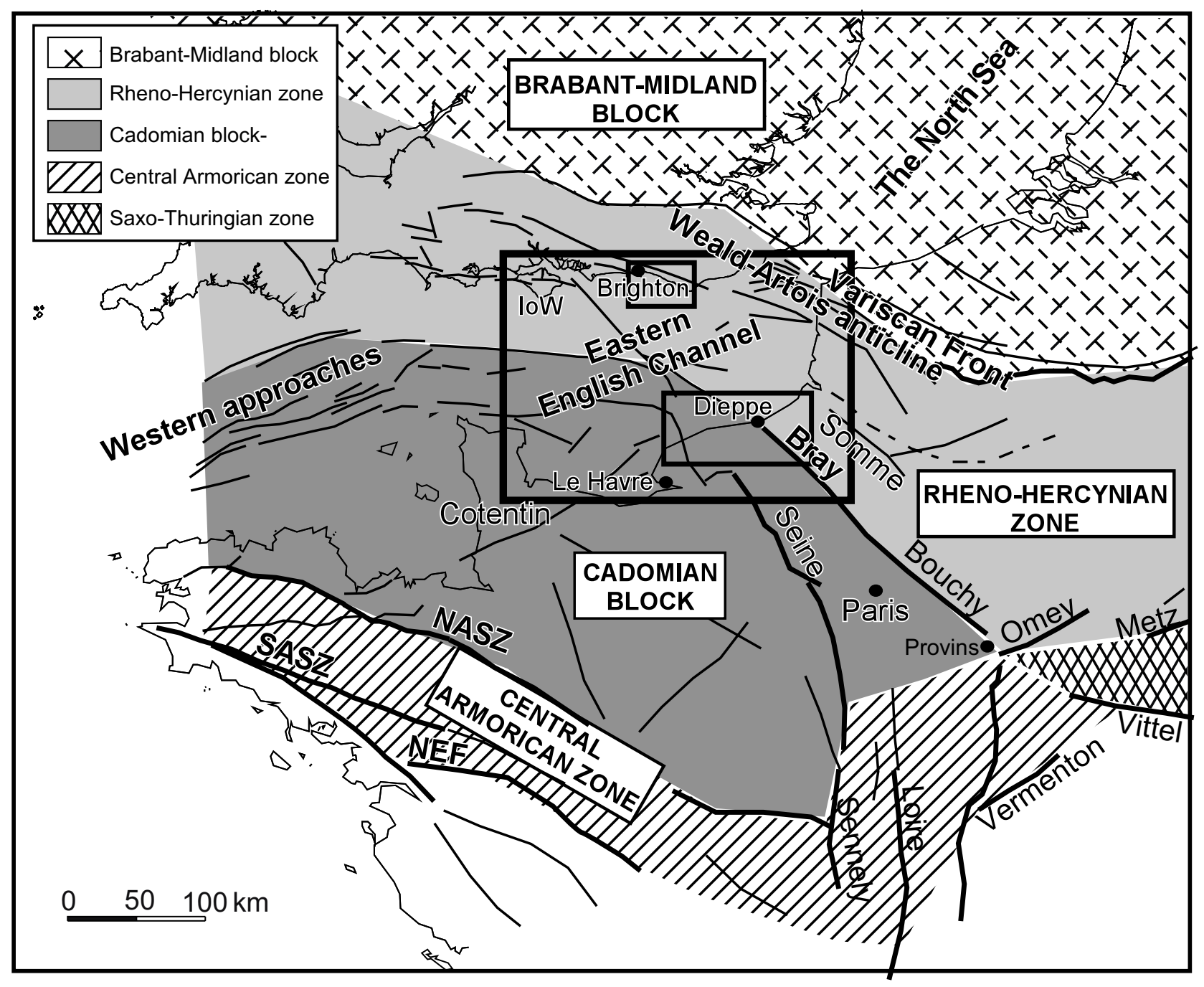

Fig. 1, Duperret et al., 2011 

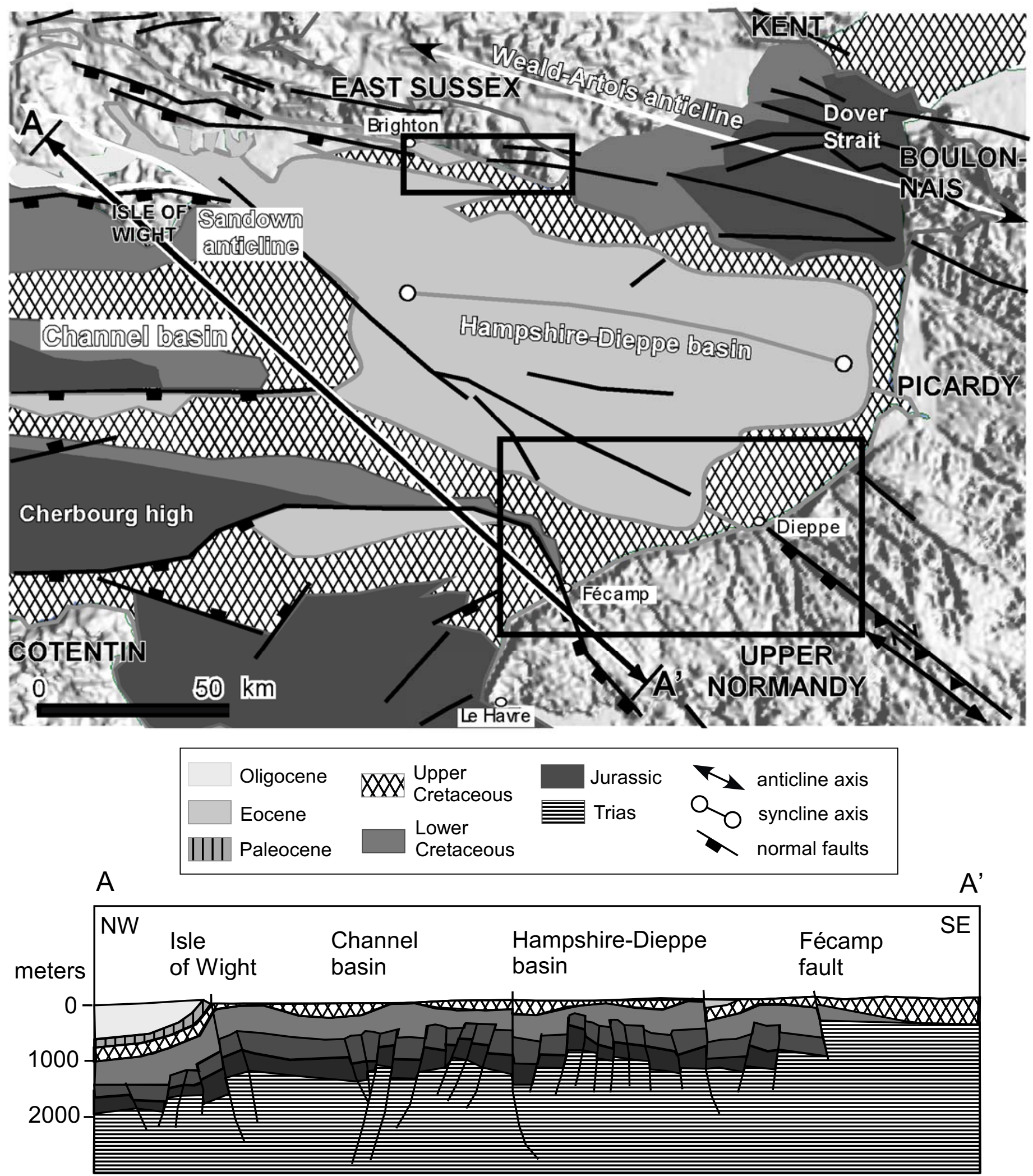

Figure 2, Duperret et al., 2011 


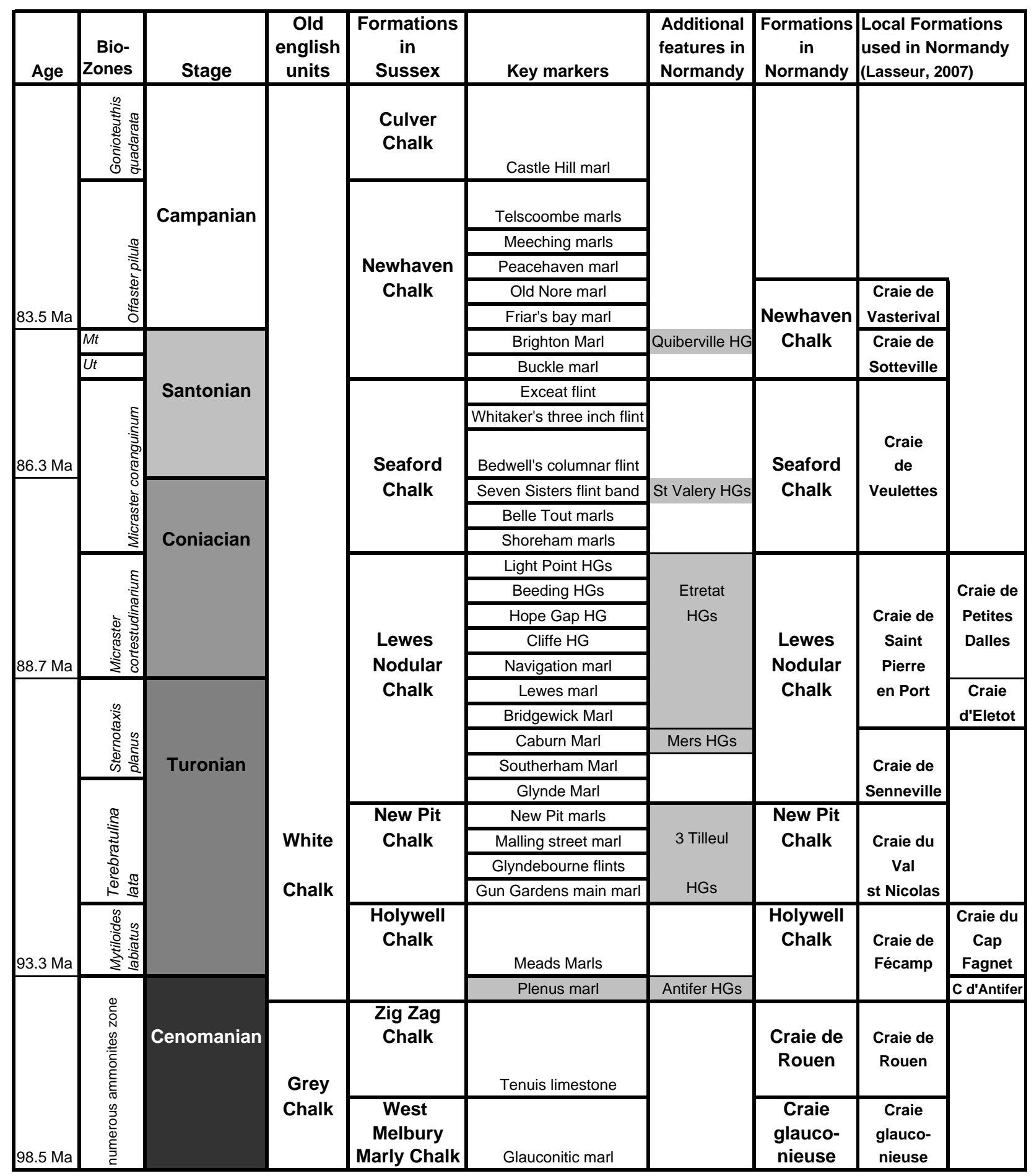

Figure 3, Duperret et al., 2011 

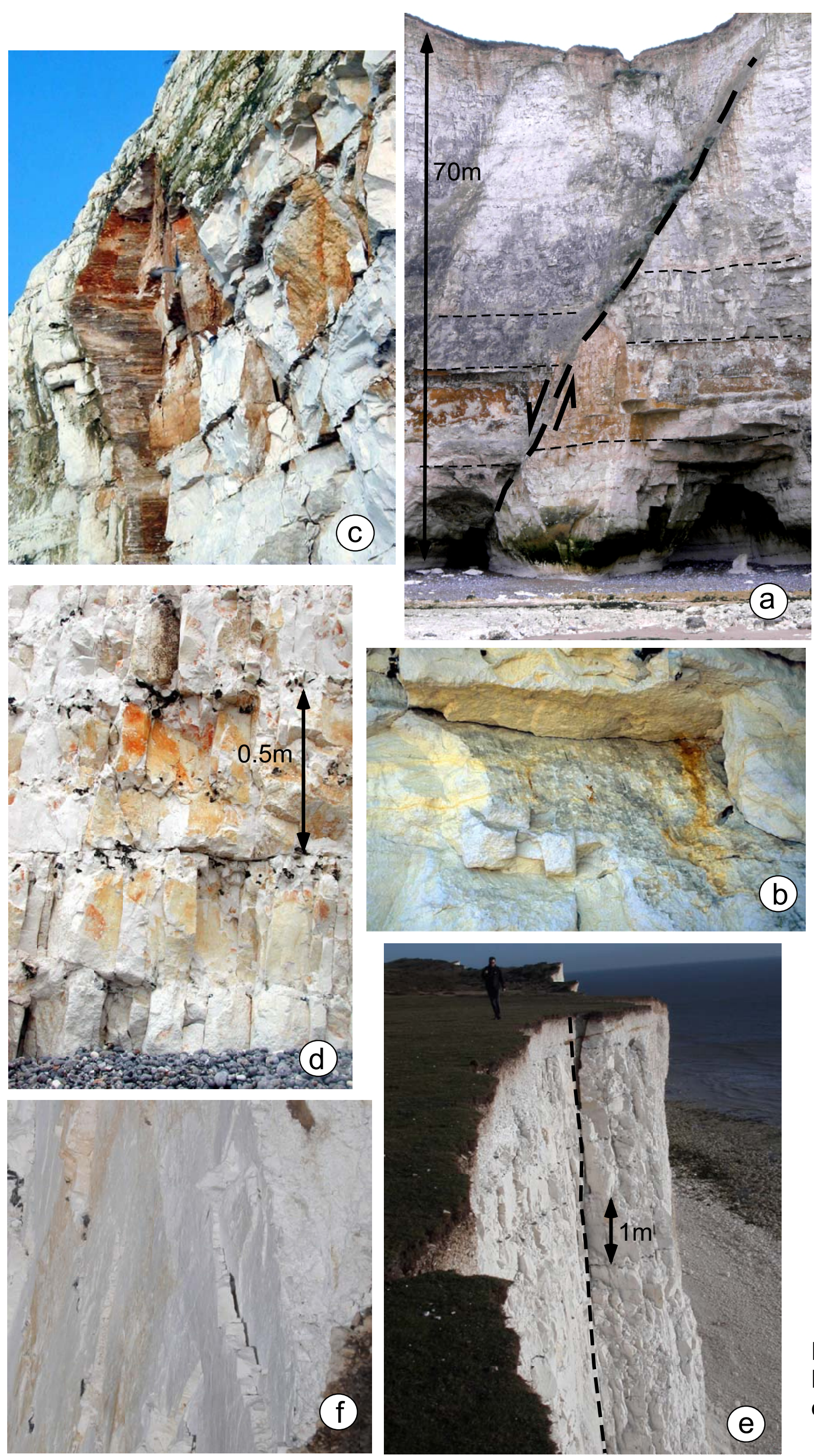

Figure 4, Duperret et al., 2011 

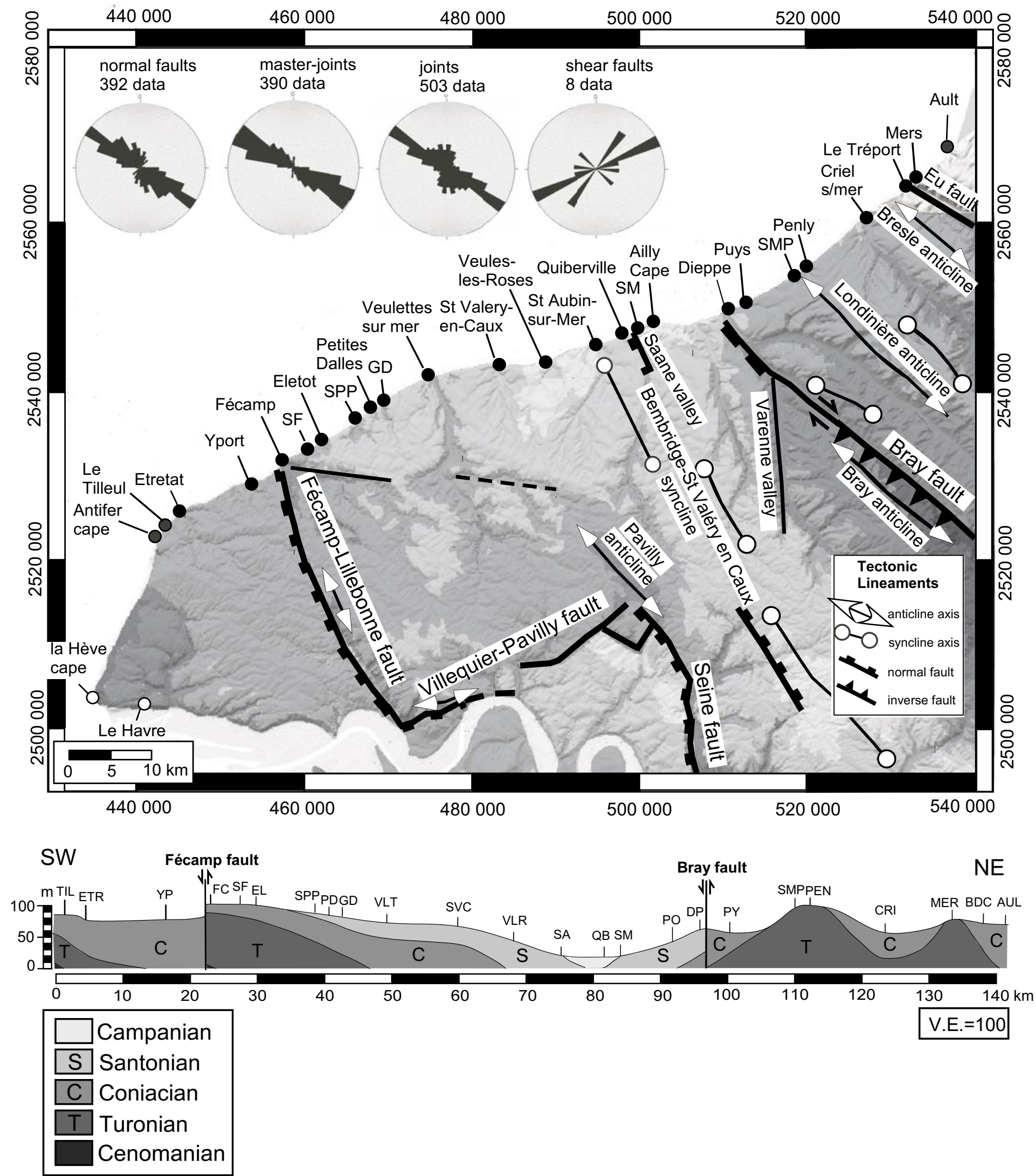

Figure 5, Duperret et al., 2011 


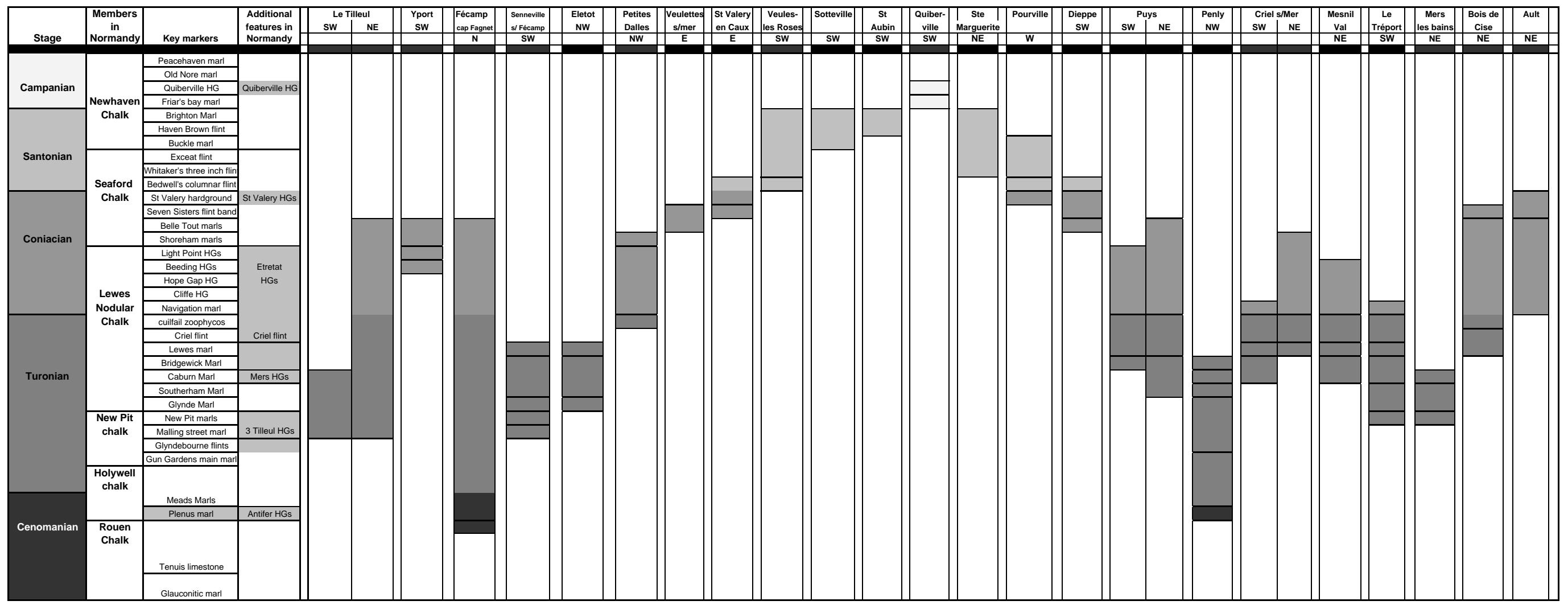

Figure 6, Duperret et al., 2011 

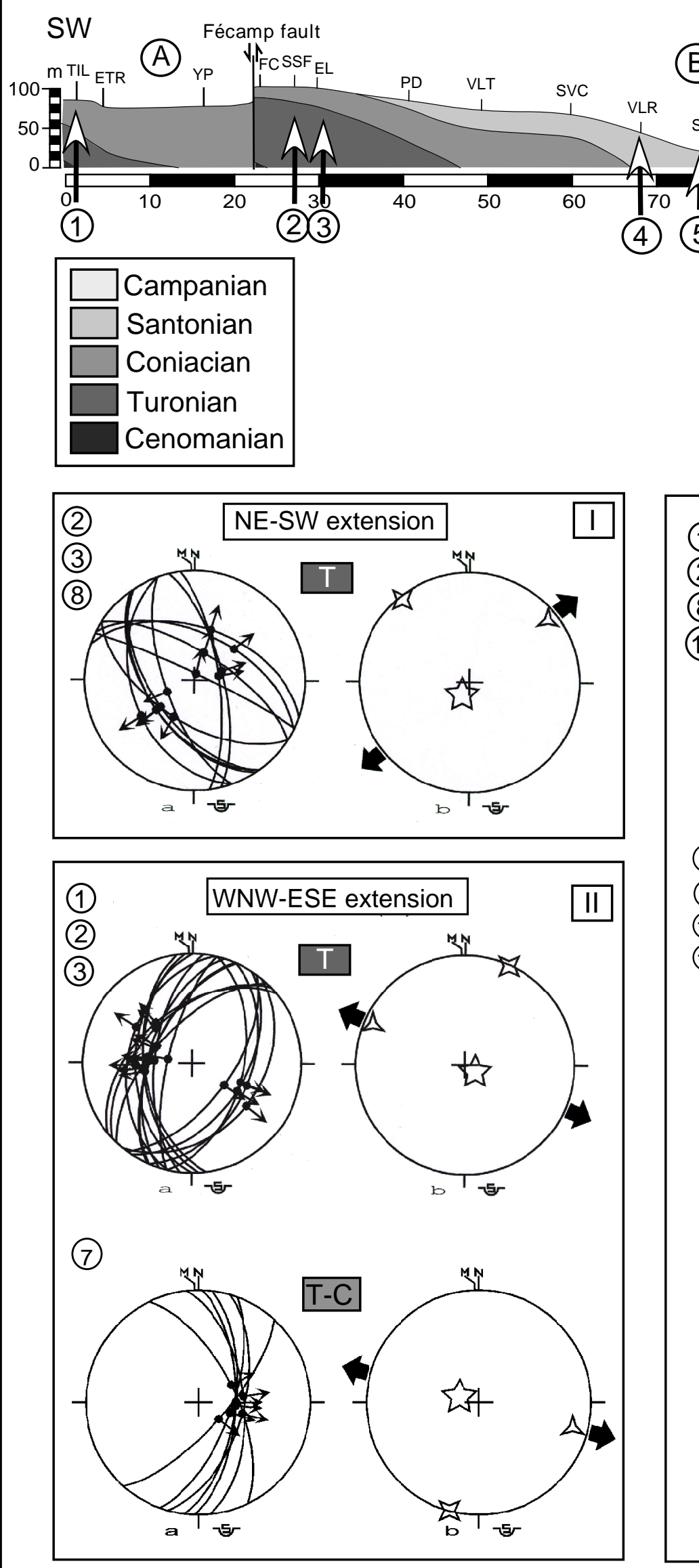

(B)

$\begin{array}{lll}\text { Bray fault } & \text { NE } \\ \text { SMTPEN } & \text { (C) MER BDCAUL }\end{array}$ CRI MER BDCAUL

(4) (5) (6) (8) (9) (10)(11)

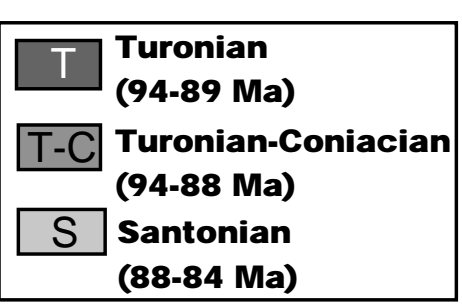

V.E. $=100$
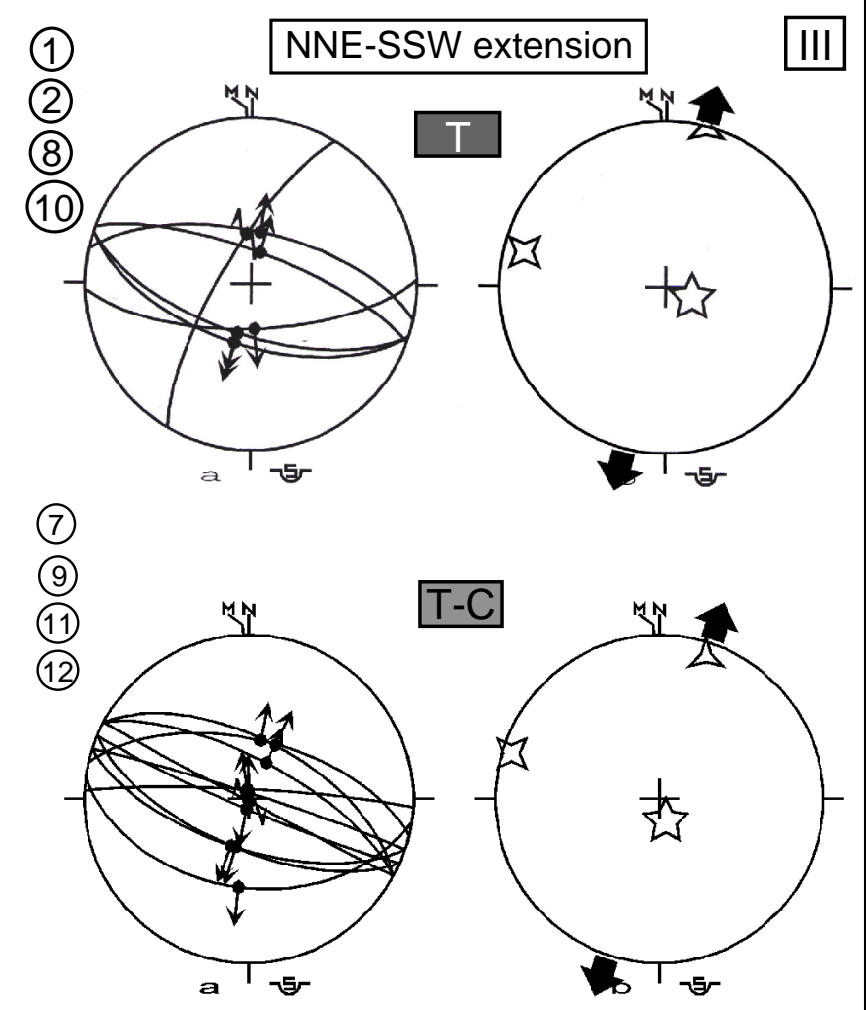

(7)

(9)

(4)

(5)
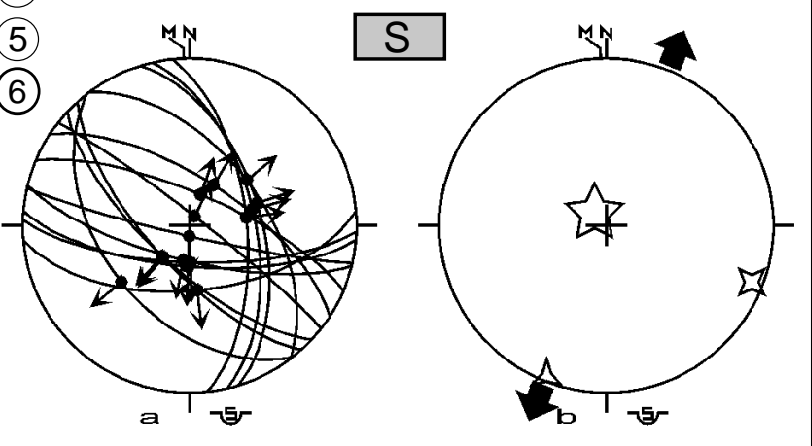

Figure 7, Duperret et al., 2011 


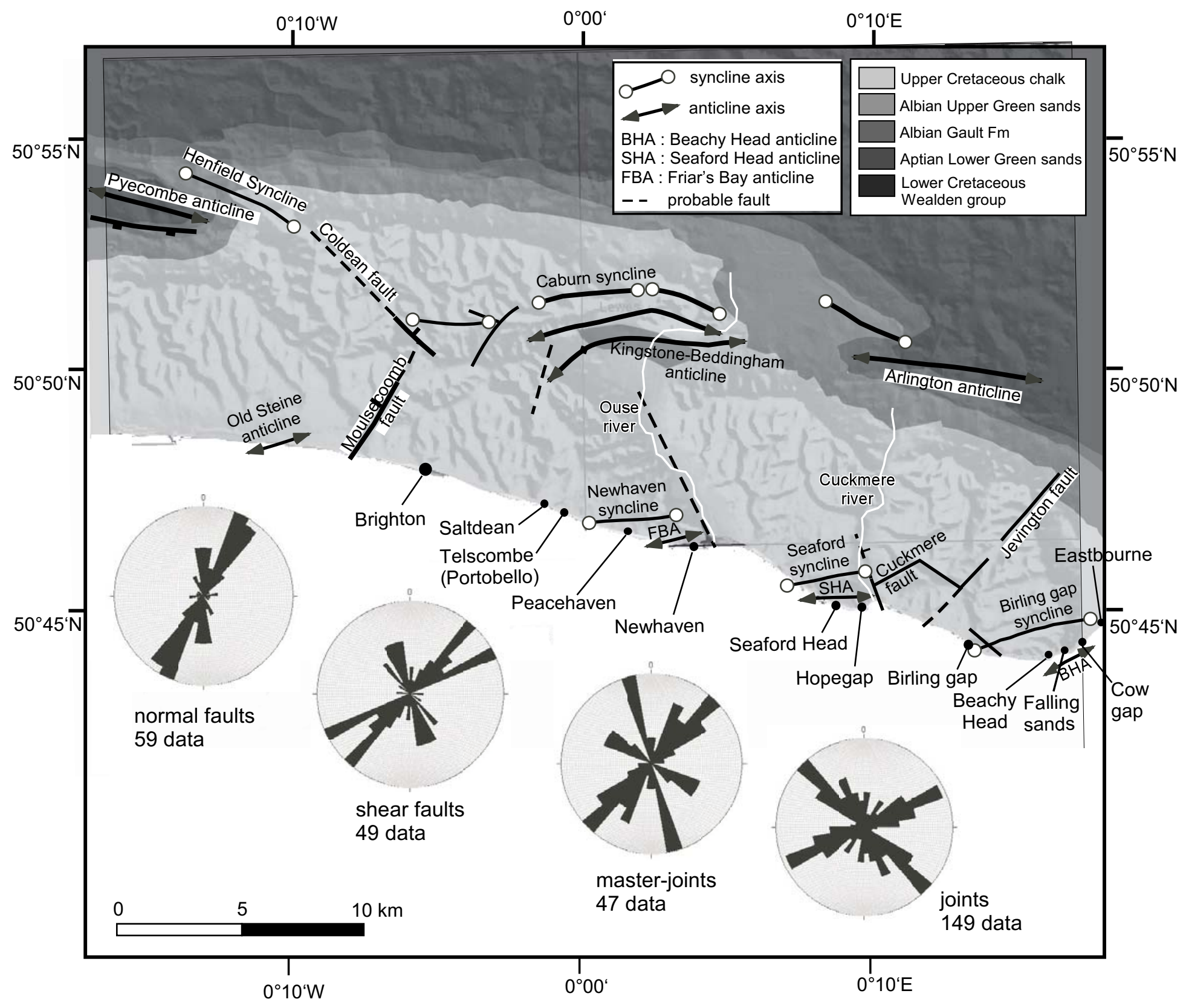

Figure 8, Duperret et al., 2011 


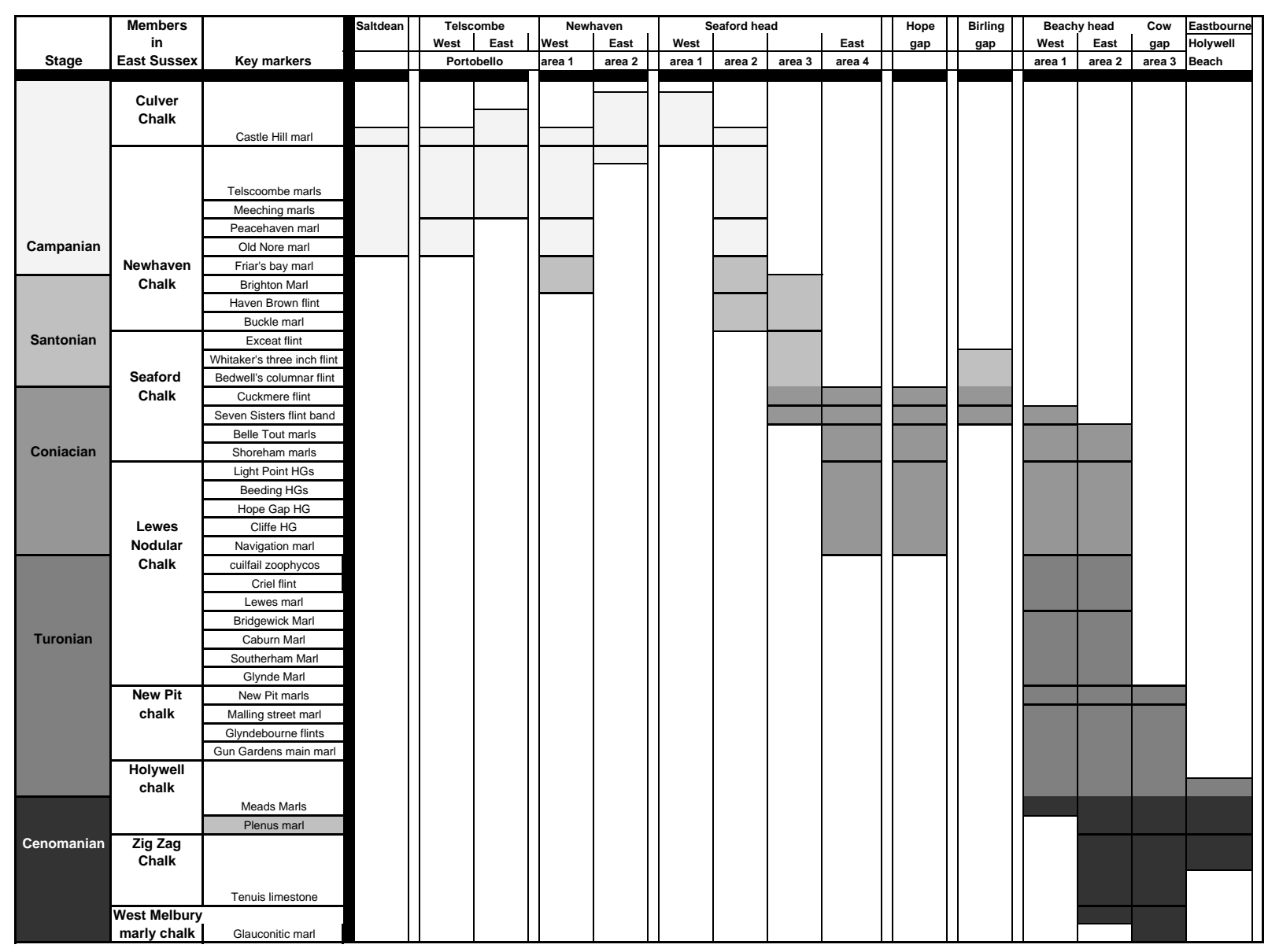


NW

$m$ Saltdean

Friar's Bay Seaford Head anticline anticline

SE

Beachy Head anticline

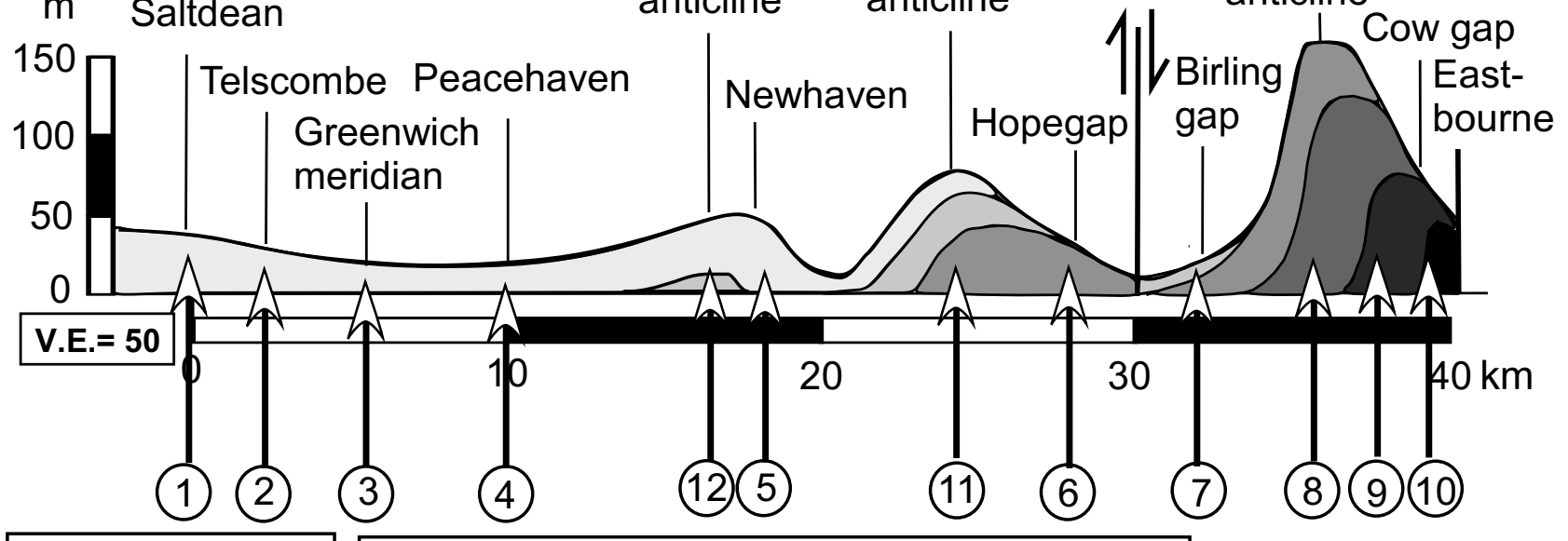

\begin{tabular}{|l|l}
\hline & Campanian \\
\hline & Santonian \\
$\square$ & Coniacian \\
$\square$ & Turonian \\
& Cenomanian \\
& Albo-Aptian \\
\hline
\end{tabular}
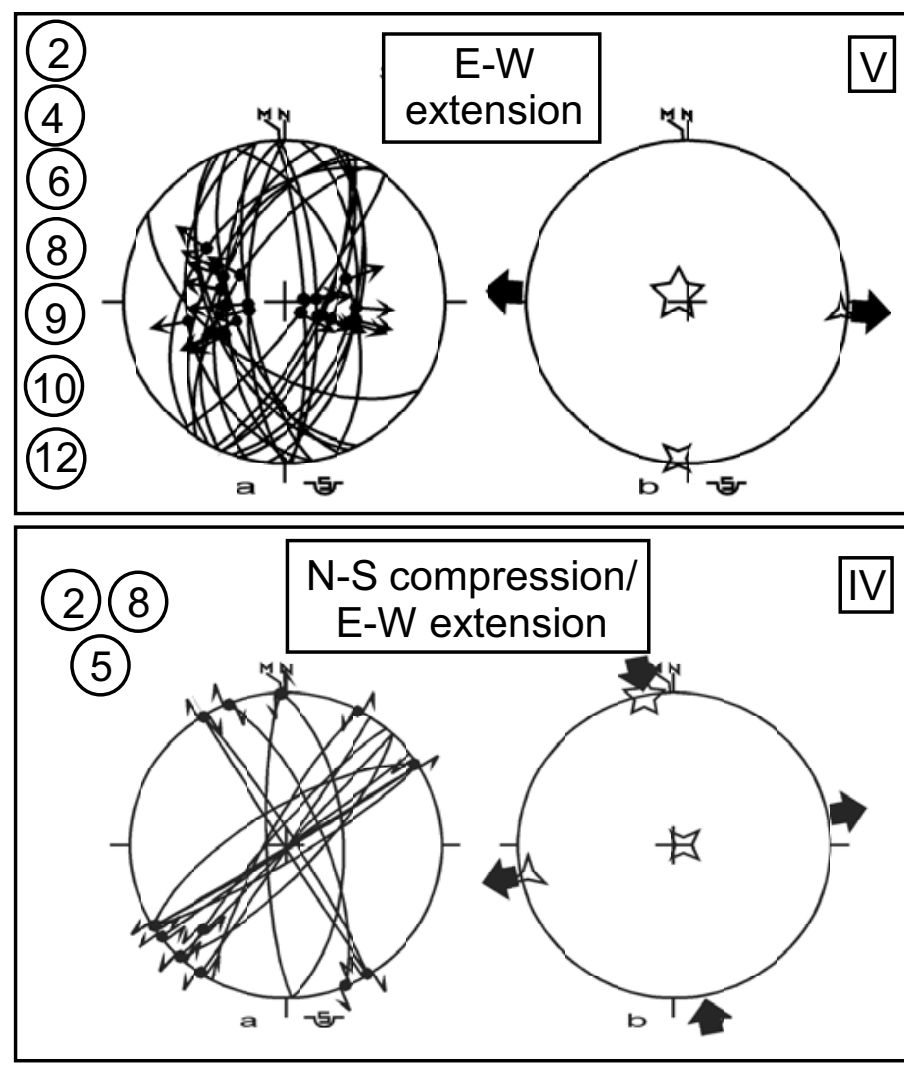

(9) (10) (11) $\begin{gathered}\text { NNE-SSW extension/ } \\ \text { ESE-WNW compression }\end{gathered}$
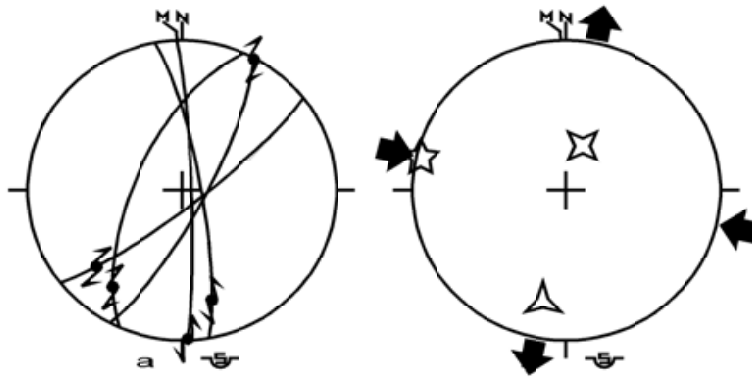

Figure 10, Duperret et al., 2011 


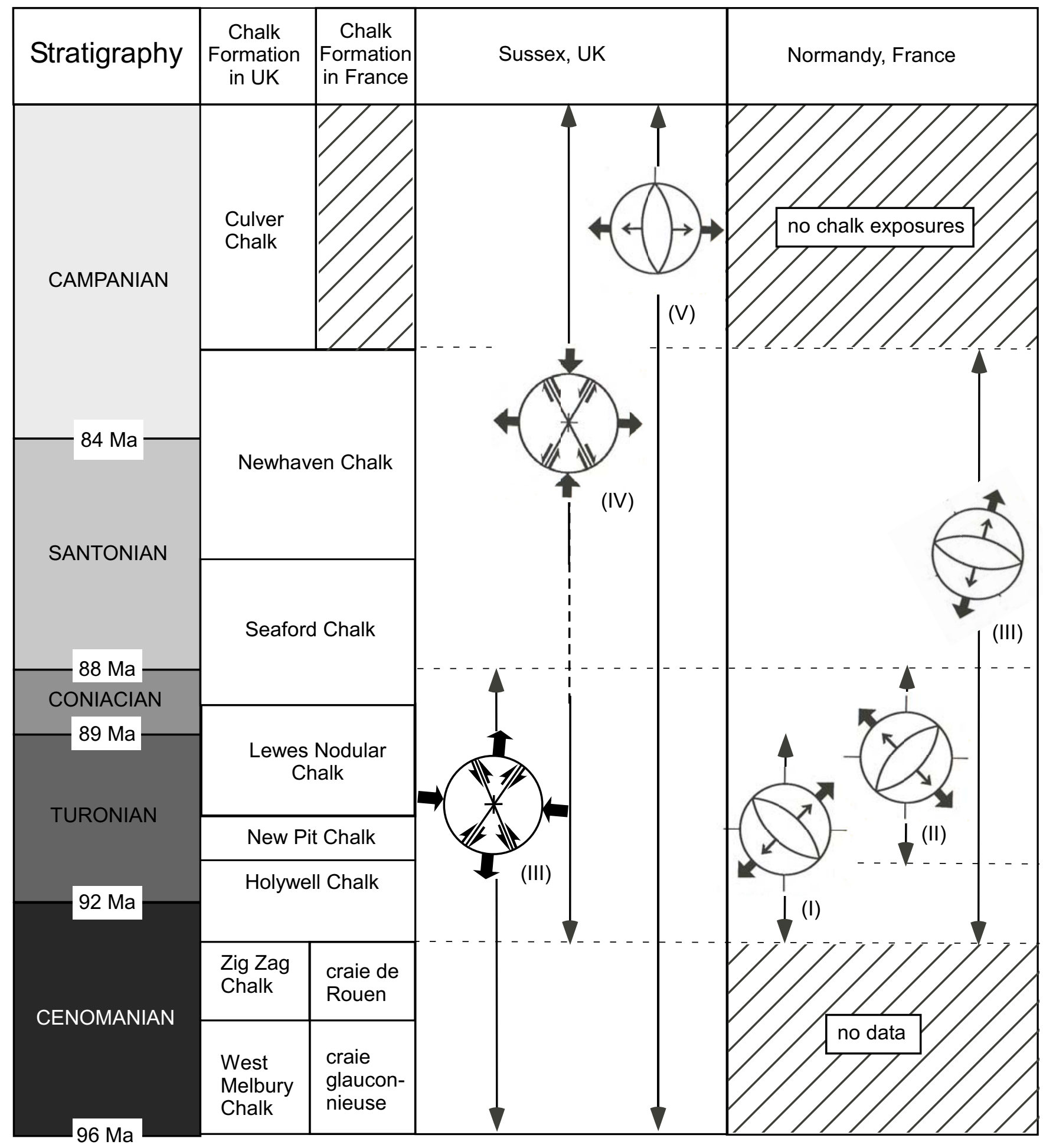

Figure 11, Duperret et al., 2011 


\begin{tabular}{|c|c|c|c|c|c|c|}
\hline Location in Normandy & joints & $\begin{array}{c}\text { master- } \\
\text { joints }\end{array}$ & $\begin{array}{c}\text { normal } \\
\text { faults }\end{array}$ & $\begin{array}{l}\text { shear } \\
\text { faults }\end{array}$ & $\begin{array}{c}\text { Total } \\
\text { fracture }\end{array}$ & Block \\
\hline $\begin{array}{c}\text { Ault } \\
50^{\circ} 06^{\prime} 06^{\prime \prime} \mathrm{N}-1^{\circ} 26^{\prime} 50 " \mathrm{E}\end{array}$ & 53 & 7 & 4 & & 64 & $C$ \\
\hline $\begin{array}{c}\text { Bois de cise } \\
50^{\circ} 05^{\prime} 50^{\prime \prime} \mathrm{N}-1^{\circ} 26^{\prime} 25^{\prime} \mathrm{E}\end{array}$ & 36 & 21 & 16 & & 73 & $C$ \\
\hline $\begin{array}{c}\text { Mers les Bains } \\
50^{\circ} 04^{\prime} \mathrm{N}-1^{\circ} 23^{\prime} 21^{\prime \prime} \mathrm{E}\end{array}$ & & & 8 & & 8 & $C$ \\
\hline $\begin{array}{c}\text { Mesnil-Val } \\
50^{\circ} 02^{\prime} 43^{\prime \prime} \mathrm{N}-1^{\circ} 19^{\prime} 50 " \mathrm{E}\end{array}$ & & 8 & 4 & & 12 & $C$ \\
\hline $\begin{array}{c}\text { Criel sur mer } \\
50^{\circ} 02^{\prime} 10^{\prime \prime} \mathrm{N}-1^{\circ} 19^{\prime} 07^{\prime \prime E}\end{array}$ & 62 & 36 & 5 & 1 & 104 & $C$ \\
\hline $\begin{array}{c}\text { Penly } \\
49^{\circ} 58^{\prime} 17^{\prime \prime N}-1^{\circ} 12^{\prime} 17^{\prime \prime E}\end{array}$ & 26 & 51 & 6 & & 83 & C \\
\hline $\begin{array}{c}\text { Puys } \\
49^{\circ} 56^{\prime} 17^{\prime \prime N}-1^{\circ} 06^{\prime} 36 " \mathrm{E}\end{array}$ & 6 & 24 & 22 & 5 & 57 & $C$ \\
\hline $\begin{array}{c}\text { Dieppe } \\
49^{\circ} 55^{\prime} 30^{\prime \prime} \mathrm{N}-1^{\circ} 03^{\prime} 50 " \mathrm{E}\end{array}$ & 12 & 1 & 4 & 0 & 17 & $C$ \\
\hline $\begin{array}{c}\text { Cap d'Ailly } \\
49^{\circ} 55^{\prime} 05^{\prime \prime} \mathrm{N}-0^{\circ} 57^{\prime} 19^{\prime \prime E}\end{array}$ & 1 & 10 & 2 & & 13 & $B$ \\
\hline $\begin{array}{c}\text { Ste Marguerite s/mer } \\
49^{\circ} 54^{\prime} 50^{\prime \prime} \mathrm{N}-0^{\circ} 57^{\prime} 03^{\prime \prime} \mathrm{E}\end{array}$ & & 12 & 11 & & 23 & $B$ \\
\hline $\begin{array}{c}\text { Quiberville } \\
49^{\circ} 54^{\prime} 14^{\prime \prime} \mathrm{N}-0^{\circ} 55^{\prime} 15^{\prime \prime} \mathrm{E}\end{array}$ & 34 & 20 & 67 & 1 & 122 & B \\
\hline $\begin{array}{c}\text { St Aubin } \\
49^{\circ} 53^{\prime} 35^{\prime \prime} \mathrm{N}-0^{\circ} 52^{\prime} 12 " \mathrm{E}\end{array}$ & & 5 & 52 & & 57 & $B$ \\
\hline $\begin{array}{c}\text { Sotteville s/mer } \\
49^{\circ} 53^{\prime} 12^{\prime \prime} \mathrm{N}-0^{\circ} 49^{\prime} 47 " \mathrm{E}\end{array}$ & & 15 & 21 & & 36 & $B$ \\
\hline $\begin{array}{c}\text { Veules les Roses } \\
49^{\circ} 52^{\prime} 08^{\prime \prime} \mathrm{N}-0^{\circ} 47^{\prime} 13^{\prime \prime E}\end{array}$ & 14 & 20 & 83 & & 117 & $B$ \\
\hline $\begin{array}{l}\text { St Valéry en caux } \\
49^{\circ} 52^{\prime} 10^{\prime \prime} \mathrm{N}-0^{\circ} 43^{\prime} \mathrm{E}\end{array}$ & 12 & 13 & 19 & & 44 & $B$ \\
\hline $\begin{array}{c}\text { Veulettes s/mer } \\
49^{\circ} 51^{\prime} 10^{\prime \prime} \mathrm{N}-0^{\circ} 35^{\prime} 35^{\prime \prime E}\end{array}$ & 31 & 9 & & & 40 & $B$ \\
\hline $\begin{array}{l}\text { St Martin aux Buneaux } \\
49^{\circ} 50^{\prime} 04^{\prime \prime} \mathrm{N}-0^{\circ} 32^{\prime 26} 26^{\prime E}\end{array}$ & 4 & 13 & & & 17 & $B$ \\
\hline $\begin{array}{c}\text { Petites Dalles } \\
49^{\circ} 49^{\prime} 26^{\prime \prime} \mathrm{N}-0^{\circ} 32^{\prime} 40 " \mathrm{E}\end{array}$ & 34 & 36 & 2 & & 72 & $B$ \\
\hline $\begin{array}{c}\text { St Pierre en Port } \\
49^{\circ} 48^{\prime} 30^{\prime \prime} \mathrm{N}-0^{\circ} 29^{\prime} 05^{\prime} \mathrm{E}\end{array}$ & 32 & 58 & & & 90 & $B$ \\
\hline $\begin{array}{c}\text { Eletot } \\
49^{\circ} 47^{\prime} 12^{\prime \prime} \mathrm{N}-0^{\circ} 27^{\prime} 04 " \mathrm{E} \\
\end{array}$ & 68 & & 13 & & 81 & $B$ \\
\hline $\begin{array}{c}\text { Senneville s/Fécamp } \\
49^{\circ} 46^{\prime} 53^{\prime \prime} \mathrm{N}-0^{\circ} 24^{\prime} 48^{\prime \prime E}\end{array}$ & 8 & & 24 & & 32 & B \\
\hline $\begin{array}{c}\text { Fécamp } \\
49^{\circ} 46^{\prime} 04^{\prime \prime} \mathrm{N}-0^{\circ} 22^{\prime} 50^{\prime \prime E}\end{array}$ & 32 & & 5 & & 37 & $B$ \\
\hline $\begin{array}{c}\text { Yport } \\
49^{\circ} 44^{\prime} 25^{\prime \prime} \mathrm{N}-0^{\circ} 18^{\prime} 50 " \mathrm{E}\end{array}$ & 19 & 22 & & & 41 & $\bar{A}$ \\
\hline $\begin{array}{c}\text { Le Tilleul } \\
49^{\circ} 41^{\prime} 47^{\prime \prime} \mathrm{N}-0^{\circ} 12^{\prime} 16^{\prime \prime} \mathrm{E}\end{array}$ & 22 & 11 & 22 & 2 & 57 & $A$ \\
\hline 24 sites & 506 & 392 & 390 & 9 & 1297 & \\
\hline
\end{tabular}




\begin{tabular}{|c|ccccc|}
\hline Sussex location & joints & $\begin{array}{c}\text { master- } \\
\text { joints }\end{array}$ & $\begin{array}{c}\text { normal } \\
\text { faults }\end{array}$ & $\begin{array}{c}\text { shear } \\
\text { faults }\end{array}$ & $\begin{array}{c}\text { Total } \\
\text { fractures }\end{array}$ \\
\hline $\begin{array}{c}\text { Cow Gap } \\
50^{\circ} 44^{\prime} 54^{\prime \prime} \mathrm{N}-0^{\circ} 16^{\prime} \mathrm{E}\end{array}$ & 16 & & 3 & 4 & 23 \\
\hline $\begin{array}{c}\text { Beachy Head } \\
50^{\circ} 44^{\prime} 10^{\prime \prime} \mathrm{N}-0^{\circ} 14^{\prime} 24^{\prime \prime} \mathrm{E}\end{array}$ & 3 & & 15 & 24 & 42 \\
\hline $\begin{array}{c}\text { Birling Gap } \\
50^{\circ} 44^{\prime} 35^{\prime \prime} \mathrm{N}-0^{\circ} 12^{\prime} 044^{\prime \prime} \mathrm{E}\end{array}$ & 45 & 2 & & & 47 \\
\hline $\begin{array}{c}\text { Hopegap } \\
50^{\circ} 45^{\prime} 30^{\prime \prime} \mathrm{N}-0^{\circ} 08^{\prime} 40^{\prime \prime} \mathrm{E}\end{array}$ & 19 & 11 & 3 & & 14 \\
\hline $\begin{array}{c}\text { Seaford Head } \\
50^{\circ} 45^{\prime} 32^{\prime \prime} \mathrm{N}-0^{\circ} 08^{\prime} 10^{\prime \prime} \mathrm{E}\end{array}$ & 19 & 12 & 3 & 46 \\
\hline $\begin{array}{c}\text { Newhaven } \\
50^{\circ} 46^{\prime} 52^{\prime \prime} \mathrm{N}-0^{\circ} 02^{\prime} 50^{\prime \prime} \mathrm{E}\end{array}$ & & 22 & 21 & 7 & 50 \\
\hline $\begin{array}{c}\text { Peacehaven } \\
50^{\circ} 47^{\prime} 24^{\prime \prime} \mathrm{N}-0^{\circ} 00^{\prime} 244^{\prime \prime} \mathrm{E}\end{array}$ & & & 4 & 8 & 12 \\
\hline $\begin{array}{c}\text { Telscoombe } \\
50^{\circ} 47^{\prime} 41^{\prime \prime} \mathrm{N}-0^{\circ} 01^{\prime} 177^{\prime \prime} \mathrm{E}\end{array}$ & & & 1 & 7 & 8 \\
\hline 8 sites & 83 & 47 & 59 & 53 & 242 \\
\hline
\end{tabular}

Table 2, Duperret et al., 2011 


\section{Normandy}

\begin{tabular}{|l|l|l|c|c|c|c|c|c|l|}
\hline \multicolumn{1}{|c|}{ Sites } & Stratigraphy & $\mathbf{N}$ & $\sigma 1$ & $\sigma 2$ & $\sigma 3$ & $\mathbf{\Phi}$ & $\boldsymbol{\alpha}$ & $\begin{array}{c}\text { RUP } \\
(\%)\end{array}$ & $\begin{array}{l}\text { Tectonic } \\
\text { regime }\end{array}$ \\
\hline $2,3,8$ & Turonian & 12 & $212 / 79$ & $321 / 03$ & $051 / 10$ & 0.3 & 8 & 30 & $\begin{array}{l}\text { NE-SW } \\
\text { Extension }\end{array}$ \\
\hline $1,2,3$ & Turonian & 18 & $123 / 81$ & $024 / 01$ & $293 / 09$ & 0.3 & 5 & 15 & $\begin{array}{l}\text { WNW-ESE } \\
\text { extension }\end{array}$ \\
\hline $1,2,8,10$ & Turonian & 6 & $110 / 76$ & $284 / 14$ & $041 / 01$ & 0.4 & 9 & 37 & N-S extension \\
\hline $7,9,12,11$ & $\begin{array}{l}\text { Turonian- } \\
\text { Coniacian }\end{array}$ & 10 & $164 / 79$ & $287 / 06$ & $018 / 09$ & 0.4 & 24 & 45 & $\begin{array}{l}\text { NNE-SSW } \\
\text { extension }\end{array}$ \\
\hline 7 & $\begin{array}{l}\text { Turonian- } \\
\text { Conacian }\end{array}$ & 7 & $287 / 76$ & $195 / 00$ & $105 / 14$ & 0.2 & 1 & 10 & $\begin{array}{l}\text { WNW-ESE } \\
\text { extension }\end{array}$ \\
\hline $4,5,6$ & $\begin{array}{l}\text { Santonian- } \\
\text { Campanian }\end{array}$ & 15 & $317 / 82$ & $111 / 08$ & $202 / 04$ & 0.1 & 11 & 41 & $\begin{array}{l}\text { NNE-SSW } \\
\text { extension }\end{array}$ \\
\hline
\end{tabular}

\section{Sussex}

\begin{tabular}{|l|l|l|l|l|l|l|l|l|l|}
\hline Sites & Stratigraphy & $\mathbf{N}$ & $\sigma 1$ & $\sigma 2$ & $\sigma 3$ & $\Phi$ & $\alpha$ & $\begin{array}{l}\text { RUP } \\
\text { (\%) }\end{array}$ & Tectonic regime \\
\hline $10,9,8,6$, & $\begin{array}{l}\text { Cenomanian, } \\
\text { Santonian, } \\
\text { Campanian }\end{array}$ & 23 & $309 / 84$ & $184 / 04$ & $093 / 05$ & 0.2 & 7 & 30 & E-W extension (E) \\
\hline $8,2,5$ & $\begin{array}{l}\text { Turonian to } \\
\text { Campanian }\end{array}$ & 15 & $349 / 01$ & $089 / 85$ & $259 / 05$ & 0.4 & 20 & 40 & $\begin{array}{l}\text { N-S compression/ } \\
\text { E-W extension (X) }\end{array}$ \\
\hline $10,9,11$ & $\begin{array}{l}\text { Cenomanian } \\
\text { to Coniacian }\end{array}$ & 5 & $283 / 03$ & $020 / 64$ & $191 / 25$ & 0.7 & 11 & 41 & $\begin{array}{l}\text { ESE-WNW } \\
\text { compression/ NNE- } \\
\text { SSW extension (X) }\end{array}$ \\
\hline
\end{tabular}

Table 3, Duperret et al., 2011 